\title{
Is Internationalization Beneficial to Innovation? Evidence from a Meta-analysis
}

\author{
Sasa Ding ${ }^{1} \cdot$ Frank McDonald ${ }^{2} \cdot$ Yingqi Wei $^{2} \mathbb{C}$
}

Received: 4 December 2019 / Revised: 1 July 2021 / Accepted: 5 July 2021 /

Published online: 18 August 2021

(C) The Author(s) 2021

\begin{abstract}
This paper conducts a meta-analytical review to examine the impact of internationalization on innovation, with particular attention to the role of research design factors that may confound causal inferences. The existing literature is examined (1) to determine the average effect of internationalization on innovation and (2) to assess how variations in key aspects of research design has affected results. Analysis of 99 studies reveals that the effects of internationalization on innovation are diverse but are generally positive, albeit the effect sizes are mostly small to moderate. The inferred magnitude of such effects is influenced by research design factors and that country-context matters. The results suggest that internationalization measurements, data characteristics and statistical artifacts affect the variations in effect sizes. We conclude with a discussion of opportunities and challenges in future research on the internationalization-innovation nexus.
\end{abstract}

Keywords Internationalization · Innovation $\cdot$ Meta-analysis $\cdot$ Research design factors

Yingqi Wei

Y.Wei@leeds.ac.uk

Sasa Ding

dingss@swufe.edu.cn

Frank McDonald

F.E.McDonald@leeds.ac.uk

1 School of International Business, Southwest University of Finance and Economics, Chengdu 611130, China

2 Leeds University Business School, University of Leeds, Leeds LS2 9JT, UK 


\section{Introduction}

The nature of the relationships between internationalization and innovation (the internationalization-innovation nexus) is an important consideration for firms that undertake cross-border activities. Firms engaging in exporting and FDI may experience innovation effects even if this is not the primary motivation for internationalization. Understanding the direct effects of internationalization on innovation and the indirect consequences on innovation from internationalization is an important consideration for private and public policy. Trade and investment liberalization is considered to enhance innovation by firms and thereby boost productivity in home countries (Tse et al., 2017; Xie \& Li, 2018). Robust evidence in this area is therefore important for managers engaged in developing international strategies and managerial systems and for national and international policymakers concerned with promoting innovation.

A variety of theoretical approaches are used to examine the particular aspects in the internationalization-innovation nexus including resource-based view (RBV), knowledge-based view (KBV), dynamic-capability view (DCV), organizational learning theory, network theory, and spillovers perspectives. Most of these approaches predict positive outcomes from internationalization (e.g., Piperopoulos et al., 2018; Sun \& Lee, 2013; Wang \& Ma, 2018; Xie \& Li, 2018). Some literature, however, identifies negative outcomes from internationalization because of significant costs from increased uncertainty and complexity (Hitt et al., 1997; Kafouros et al., 2008). The multiple theoretical perspectives used to examine relationships within the nexus therefore provide uncertain postulations on the net effects of internationalization on innovation. Empirical studies based on an assortment of research approaches provide inconsistent findings (Appendix 1). A variety of firm-level contextual factors has been employed to examine a range of causal paths in the nexus. The type of contextual factors considered partly depends on the theoretical underpinnings that influence the kind of causal paths under examination. Firm size and technology intensity of industries are normally considered as important contextual factors. Other factors such as the level of development of host countries and types of internationalization and innovation are sometimes studied. The mixed results in the literature suggest that improvements in research design connected to adequately addressing contextual factors considered in the various theoretical approaches would improve understanding on the impact of internationalization on innovation.

Using meta-analytical techniques, this paper aims to answer two research questions. (1) What is the direction and strength of the impact of internationalization on firm innovation? (2) Which key research design issues influence the estimates of the effects of internationalization on firm innovation?

Meta-analysis offers an effective and systematic tool to analyze a large collection of findings from independent quantitative studies to synthesize evidence. Although this type of analysis "cannot test the competing views against one another", it is useful in examining "the direction and significance of the bivariate relationships" (Bergh et al., 2016, p. 478). This approach is widely used in various topics in International Business (e.g., Bausch \& Krist, 2007; Beugelsdijk et al., 2018; Schwens 
et al., 2018; Tang \& Gudergan, 2018; Zhao et al., 2017) and in innovation studies (e.g., Bowen et al., 2010; Camisón-Zornoza et al., 2004; Grinstein, 2008). To the best of our knowledge, few meta studies explicitly examine the relationship between internationalization and firm innovation. An exception is Rosenbusch et al. (2019) that considers the impact of business environment factors on a specific aspect of the nexus, i.e. offshoring of $R \& D$ activities (or $R \& D$ internationalization). Our study assesses the more general effects by including manufacturing and sales as well as $R \& D$ internationalization and focuses on the effect of research design factors on estimates. This research paper therefore complements and extends the study by Rosenbusch et al. (2019).

Our study responds to calls to improve research design to enhance the validity and reliability of results (Dimos \& Pugh, 2016; Starbuck, 2016). These calls are also growing in International Business research (e.g., Aguinis et al., 2017; CuervoCazurra et al., 2016; Reeb et al., 2012; Steel et al., 2021). Good research design includes addressing important contextual factors and analytical techniques to improve the validity and robustness of results. This study examines these issues to assess the effects of key research design issues on the direction and effect sizes of relationships within the nexus.

The meta-analysis summarizes 99 studies published between 1998 and 2018. The results reveal that on average internationalization has a positive, though relatively small impact on innovation. Our results indicate that divergent results are related to research design factors, including the selection and measurements of key constructs, country-context, data characteristics (panel data vs. cross-sectional data and primary data vs. secondary data) and statistical artifacts (estimation methods, model specifications and endogeneity control). The study considers the effect of multidimensionality of internationalization and innovation concepts by examining the impact of different dimensions of internationalization and innovation. The study found that national differences in the magnitude, strength, and direction of the focal relationship are substantial with positive and statistically significant results found in 15 out of 21 countries and the effect sizes ranging between 0.059 (Ireland) to 0.650 (Australia). Single country studies offer important insights, but generalization should be treated with caution as it may lead to incorrect conclusions. Meta-regression results further reveal that heterogeneity of effect sizes is associated with data characteristics and estimation methods. In summary, the paper highlights the importance of internationalization to innovation and the focus on research design factors provides evidence that is potentially useful to develop theory to provide more robust postulations on the internationalization-innovation nexus.

The paper makes contributions to the International Business and Innovation literature by providing evidence on what existing studies reveal about the direction and size effects of a wide range of internationalization activities for innovation. The results also highlight how improved research design including better addressing contextual factors and data analytical techniques might improve the potency of estimates. Consideration of these key research design factors enables the proposal of "best practice" recommendations to improve the robustness of results. This study is timely as internationalization has been asserted to be good for firms (Contractor, 2007) but such assertion has not been universally supported by empirical evidence. 
Moreover, the growth of anti-globalization movements and trends towards more nationally focused policy calls the value of internationalization for innovation (Witt, 2019) into question. A more robust evidence-based view, on the extent of benefits and insights into developing research design to secure more robust results, is helpful in developing the international strategies of firms and also for national and international policy debates on the effects of globalization on innovation.

\section{Literature Review}

\subsection{Major Theories of Internationalization and Innovation}

Internationalization, defined as business expansion "across the borders of global regions and countries into different geographic locations, or markets" (Hitt et al., 1997, p. 767), may enhance innovation which concerns activities that "put [a new idea] to practice while paying special attention to its usefulness" (Camisón-Zornoza et al., 2004, p. 334). Most research on the internationalization-innovation nexus relates to the acquisition and use of resources. The theories used to investigate the nexus use different mechanisms to examine a range of aspects on how internationalization impacts on innovation. The postulations from these theories often include a range of contextual factors thought to influence relationships within the nexus. There is however no consistency on which contextual factors are considered to be important in obtaining robust results and that specify the applicability of findings. This has implications for the usefulness of results for developing strategic and managerial policies and public policy as it is often not clear if findings are applicable to the conditions faced by policymakers. Due to space constraints, we provide only a brief overview of the major theoretical perspectives, that concludes a summary of how addressing key contextual factors may help to enhance the predictive power of the various theories.

Although the approaches taken by RBV, KBV and DCV use somewhat different mechanisms to explore the relationship between resources and the development of competitive advantages, at the core, they are based on acquiring, developing, and effectively using resources to secure competitive advantages. The major distinguishing factor between these approaches is the process by which innovation leads to competitive advantages. The RBV focuses on the identification and exploitation of all resources, whereas the KBV focuses on how firms develop knowledge from their resources and DCV on cultivating routines and practices to enhance competencies. Studies using these approaches have found that internationalization can facilitate the acquisition and development of innovation by securing the specific advantages of different countries enabling the capture of ideas, information and knowledge from a greater number of new and different markets and cultural perspectives (Beugelsdijk et al., 2018; Gkypali et al., 2018; Hitt et al., 1997; Jiang et al., 2016; Kafouros et al., 2008). Organizational learning theory regards firms as learning social entities that enables the transformation of information into knowledge (Hotho et al., 2015). Organizational learning thereby complements RBV, KBV and DCV by highlighting learning mechanisms that facilitate resources to be converted into competitive 
advantages. Operating in international markets exposes firms to more, diverse and advanced market and technological knowledge, which heightens the effects of "learning by watching" (knowledge acquisition as a consequence of observing others) and "learning by doing" (knowledge acquisition as a consequence of direct experience). Learning therefore facilitates innovation through creating new and combinative knowledge and by learning how to effectively use this knowledge helps firms to develop competitive advantages (Kafouros et al., 2008; Piperopoulos et al., 2018; Salomon \& Jin, 2010; Xie \& Li, 2018).

Network theory (Almeida \& Phene, 2004; Frenz \& Ietto-Gillies, 2009; Zahra et al., 2009) provides further insights into how resources, knowledge and competencies acquired and developed by internationalization connects to innovation. Networks enhance the richness and diversity of firm's resource pools. Internationalization broadens firm's networks from domestic market to international markets and offer them opportunities to tap into many different networks. Networked relationships also offer opportunities to develop new knowledge and advance capabilities as members interact enabling effective information flows within networks. This facilitates innovation as firms embed and learn from their host business environments (Tidd, 2001).

Studies explicitly adopting the theoretical lenses of research-based approaches, organizational learning and network theory usually focus on direct acquisition of resources and capabilities and deliberate knowledge flows. Technological/knowledge spillovers perspective recognizes unintentional knowledge and information flows that go beyond business transactions or alliances (Perri \& Peruffo, 2016; Ugur et al., 2020). These flows are not normally purposefully conducted but can have an important source of knowledge that benefits innovation (Frenz \& Ietto-Gillies, 2009; Jiang et al., 2016; Kafouros et al., 2008; Liu et al., 2010). To access and benefit from this knowledge, firms must build effective formal and informal networks to embed in local/regional/national innovation systems thereby absorbing knowledge transferred by trade and FDI (Frenz \& Ietto-Gillies, 2009; Scalera et al., 2018).

In summary, the various theoretical approaches have somewhat different emphases that influence the causal paths they examine within the nexus. The RBV focuses on causal relationships based on the identification and use of any resources that can secure innovation. The KBV considers the major relationships that affect the qualities of resources that directly help to develop knowledge and thereby influence innovation. For the DCV the major causal paths revolve around the routines and practices that help to secure and develop innovation competencies from the resource base associated with internationalization. Organizational learning focus on factors related to how firms learn from engagement with the nexus, and network theory explores how inter and intra-organizational networks within the nexus impact on learning for various innovation outcomes. Spillover perspective centers on how domestic firms gain resources and knowledge helpful for innovation obtained from the activities of foreign firms in host locations.

The postulations in the causal paths that emerge from the various theoretical approaches often, but not universally, regard outcomes as being conditional on the size of firms and the level of technology that is embedded in internationalization. The effect of other fundamental contextual factors like country, types of 
internationalization, and stages of innovation are less frequently addressed in studies. This study examines the moderating effect of these key contextual factors and thereby provides evidence on their impact on the potency of estimates. Evidence on the importance of these contextual factors helps to identify some of the major elements that determine the boundary conditions in which the postulated relationships from causal paths apply (Steel et al., 2021). Evidence that key contextual factors have meaningful impact on estimates provide grounds for a more comprehensive addressing of these factors in the conceptualizations of causal chains in the various theoretical approaches used to investigate the nexus. Improved knowledge from future studies on the effect of major contextual factors would, therefore, help to identify the conditions where large innovation benefits are likely to arise. An example of addressing contextual factors for a possible causal path (based on the KBV) is given in Fig. 2. This type of approach could be applied to the other major theories used to examine the nexus.

Devoting resources to internationalization can hinder the amount that can be used for innovation (Li, 2007). Supporting sources are required to ensure the effective assimilation, absorption and utilization of resources and knowledge acquired through internationalization for innovation performance (Frenz \& Ietto-Gillies, 2009; Gkypali et al., 2018; Jiang et al., 2016; Kafouros et al., 2008). Moreover, as firms develop their international activities, organization and management become complex, increasing coordination and governance costs and the risk of losing strategic control (Tsao \& Chen, 2012). International expansion can increase firm's exposure to financial, macroeconomic, and political risks. Theft of intellectual property rights due to problems of defending these rights can lead to high risk in using internationalization to boost innovation (Hsu et al., 2015; Kafouros et al., 2008). Internationalization can exacerbate costs and risks stemming from information asymmetry and due to cultural and institutional diversity (Azar \& Drogendijk, 2014; Beugelsdijk et al., 2018; Hitt et al., 2006). Given that internationalization and innovation are both resource-intensive, costly, and risky, firms may regard them as alternative growth strategies (Jiang et al., 2016; Sasidharan \& Kathuria, 2011; Wang \& Tao, 2019; Xie \& Li, 2018). Moreover, taking advantage of the opportunities accrued from internationalization for innovation may result in imitation, reverse engineering, and technology purchasing that substitutes for innovation (Frenz \& Ietto-Gillies, 2009; Wang \& Tao, 2019; Wu \& Wu, 2014).

Theory postulates both the benefits and the costs associated with the internationalization-innovation nexus (Frenz \& Ietto-Gillies, 2009; Gkypali et al., 2018; Hsu et al., 2015; Jiang et al., 2016; Kafouros \& Buckley, 2008; Piperopoulos et al., 2018; Sambharya \& Lee, 2014; Wang \& Tao, 2019). Theory does not, therefore, provide clear predictions that internationalization will have a beneficial effect on innovation. This theoretical ambiguity implies that high quality empirical studies are crucial to provide valid and robust evidence to increase understanding on the direction and size of the predictions of causal paths in the nexus. This requires good research design that provides robust results on how internationalization affects innovation, including the effect of major contextual factors that affect outcomes. 


\subsection{Research Design Factors}

Understanding the results in the literature is complicated, by the fact there is considerable heterogeneity in research design used in studies. A review of the literature revealed a set of the key factors that are likely to affect the validity and reliability of the empirical findings: variable measurements, data characteristics representing properties of the data used and statistical artifacts.

\subsubsection{Measurement Adequacy}

The use of different measures is likely to be the cause of significantly different estimation results between studies. Measurement adequacy is an issue raised in many studies of internationalization (Hennart, 2011; Hitt et al., 2006; Li, 2007) and innovation (Hagedoorn \& Cloodt, 2003).

\section{The Internationalization Concept and its Measurement}

Internationalization is multidimensional, encompassing three main dimensions: depth, breadth, and speed (Riviere \& Bass, 2019; Schwens et al., 2018). Depth (or scale) of internationalization refers to the extent of operations conducted outside the home country. Breadth (or the spread) of internationalization indicates the spread of activities across foreign locations. Speed of internationalization is associated with the pace at which international business activities develop over time. Existing studies of internationalization and innovation have largely focused on the first two, which can be considered together as the degree of internationalization (Kirca et al., 2012; Riviere \& Bass, 2019). Many studies considering speed factors focus on the effects of the speed of innovation on internationalization rather than the influence of the pace of internationalization on innovation performance (Chetty et al., 2014). This study therefore focuses on the depth and breadth of internationalization.

Measures of the depth of internationalization often treat the outcomes from foreign operations as being independent of the breadth of internationalization. The same level of foreign sales, assets, employment and investment from one host country or from multiple host countries may, however, have very different meanings (Verbeke \& Forootan, 2012). Outcomes from multiple host countries involve more operational complexities but could also mean access to more resources, knowledge and learning opportunities. This highlights that it is important to obtain robust estimates to consider the effect of using depth or breadth as the dimension of internationalization.

Hennart (2011) provides a comprehensive overview of the major components of internationalization: foreign market penetration (the proportion of sales in foreign markets), foreign production presence (the proportion of production in foreign locations), foreign operations dispersion (the spread of firm sales and direct investment across foreign locations), country scope (the number of foreign countries a firm is present) and the diversity of foreign markets (spread of firms' presence in different national cultural environments). This fivefold categorization can be grouped in such a way with the first three capturing depth and the latter two denoting breadth (see Table 1). 


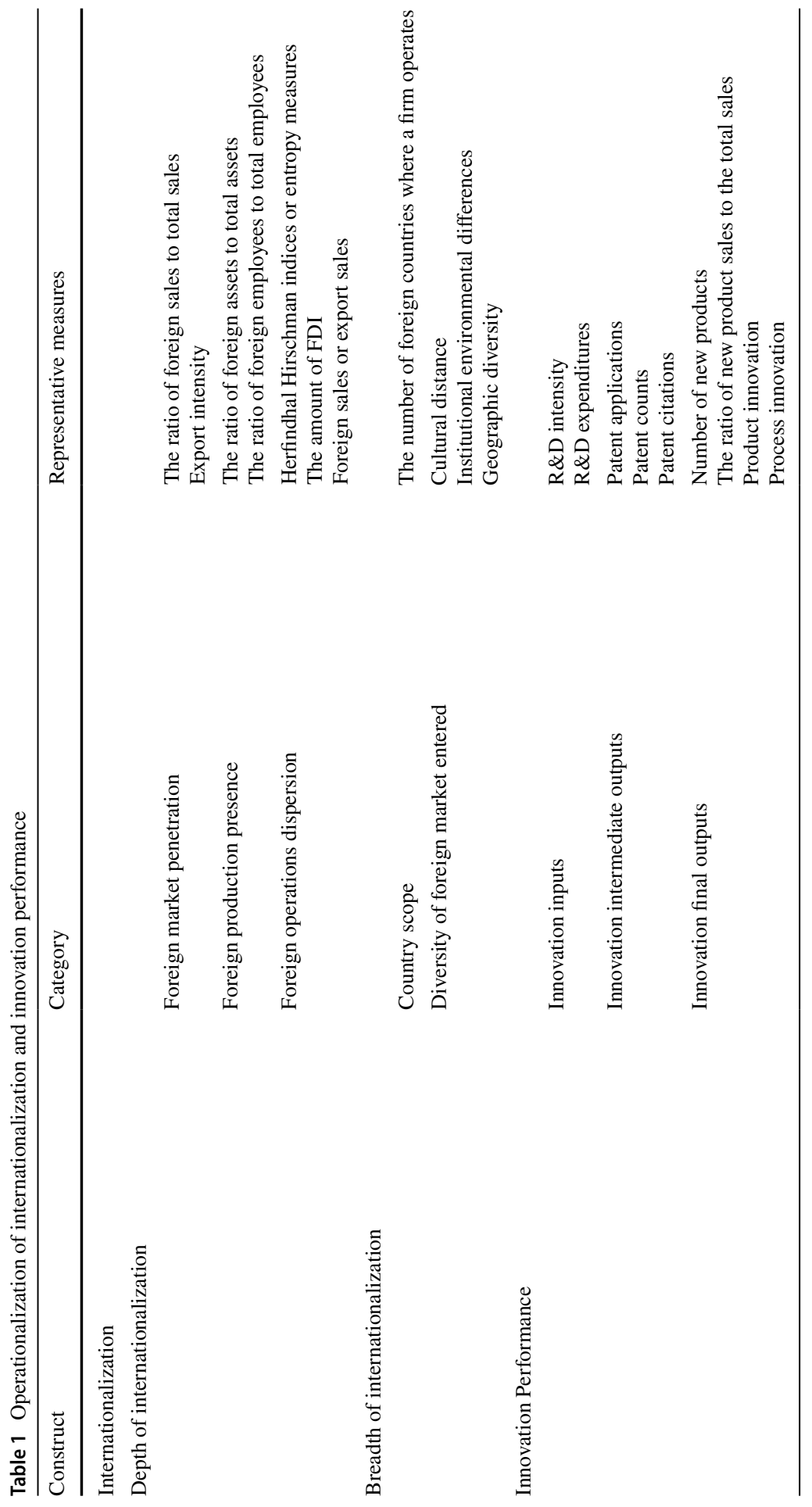




\section{The Innovation Concept and its Measurement}

Innovation has been studied from a broad range of perspectives, resulting in debates on conceptual and measurement issues (Azar \& Drogendijk, 2014; Camisón-Zornoza et al., 2004; Dziallas \& Blind, 2019; Hagedoorn \& Cloodt, 2003; Tidd, 2001). The most used is stage, i.e., inputs, intermediate outputs and final inputs. Innovation inputs are often proxied by $R \& D$ expenditures or R\&D intensity. Intermediate outputs of innovation commonly connect to developing the means to deliver new and/or improved products, captured by patents. Measurement of final innovation outputs include new product announcements, new process introductions, and new product sales. Table 1 summarizes the major factors in innovation paths.

Various comments have been made about these measures (Hagedoorn \& Cloodt, 2003; Taques et al., 2020; Tidd, 2001). Inputs measures do not measure the "efficiency" of innovation performance (Malen \& Vaaler, 2017). Undertaking innovation, or increasing innovation inputs, do not necessarily guarantee valuable outcomes and success in marketplace, hence do not capture the commercialization part of innovation definition (Malen \& Vaaler, 2017; Rosenbusch et al., 2011; Wang \& Tao, 2019). Second, firms not only rely on internal R\&D activities for innovation, but also utilize technologies embodied in equipment or other external resources. Thus, inputs may partially represent innovative activities realized at the firm level (Lachenmaier \& Wossmann, 2006). Third, not all firms have separate R\&D departments or even R\&D budgets (Yi et al., 2013). Using inputs variables could potentially under-estimate firm innovation performance, particularly for small firms (Tidd, 2001). Nevertheless, because inputs measures tend to be more readily available, this accessibility determines their wide usage in the literature.

Using patenting data is controversial (Dziallas \& Blind, 2019; Hagedoorn \& Cloodt, 2003; Taques et al., 2020). Patent measures provide a continuous and relatively objective way of measuring innovation that may be closer to market impact than inputs measures. Problems may arise however because of the differences in patenting behaviors between international and sectoral arenas and in large and small organizations (Tidd, 2001). Not all innovation outcomes are patented and not all innovations are patentable. Organizations also vary in their propensity to patent, depending on their strategy and resources (Chittoor et al., 2015; Hagedoorn \& Cloodt, 2003). For example, patents can be used to strategically improve a company's competitive advantage and put it in a favorable position in negotiations. Resource-rich firms are not only more likely to engage in patenting, but also have a larger number of sleeping (unused) patents (Dziallas \& Blind, 2019). Propensity to patent is also associated with the types of innovation. Arundel and Kabla (1998) and Brouwer and Kleinknecht (1999) show that process innovations are generally less likely to be patented, albeit there are inter-sectoral differences. The extant studies have established that patent registrations tend to be lower in services than in manufacturing (Taques et al., 2020). There are also issues connected to the same weight given to radical and incremental innovation or innovation of different quality.

Compared with the inputs and intermediate outputs measures, final outputs measures have the advantages of reflecting the technical and market success of innovation activates and cross-industry validity (Wang \& Tao, 2019) and incorporating non-patentable innovation (Wang \& Kafouros, 2009). The weaknesses include new 
product measures do not differentiate the quality of new products and could be the results of improved management practices, changes in organizational structure or the use of better quality intermediate inputs (Liu \& Qiu, 2016). New products with a radical innovation nature carry the same weight as the ones that only made incremental improvement. These issues are also applicable to process innovation measures. Finally, final output measures may not reflect only innovation but also the results of marketing efforts (Wang \& Tao, 2019) and be sensitive to economic cycles (Taques et al., 2020).

\section{Measurement Errors and Endogeneity}

The classical assumptions of econometric analysis assume that variables are measured accurately and that there are no correlations between the explanatory variables and errors, i.e., the exogeneity condition. When this condition is violated, endogeneity arises. The errors-in-explanatory-variables can cause ordinary least squares (OLS) estimation to be inconsistent and potentially affect many past conclusions (Bascle, 2008). If the assumption of a dependent variable not being subject to measurement errors does not hold, the consequences are not as severe as the presence of errors-in-explanatory-variables. Instrumental variables estimations and structural equation modelling (SEM) are common ways to seek to address measurement error problems (Bascle, 2008; Richter et al., 2016). Like many studies on the internationalization-performance relationship that frequently overlook measurement error problems (Bausch \& Krist, 2007), we could not account for the effects of measurement error in the meta-analysis of this paper because few studies reported information on data reliability. Nevertheless, as representative measures of internationalization and innovation (see Table 1) can be objectively audited, we expect that measurement errors are less likely to be a significant problem in internationalization-innovation studies.

\subsubsection{Data Characteristics}

\section{Panel Data vs. Cross-sectional Data}

The use of data should be matched with research questions (Bono \& McNamara, 2011). In this area the dimension of time is a critical issue (Damijan \& Kostevc, 2015; Filipescu et al., 2013). The innovation benefits of internationalization may take time to materialize. There is also the causality direction between internationalization and innovation, i.e., which one comes first Cross-sectional data capture a snapshot within the process therefore, as Bono and McNamara (2011) noted, "[r] esearchers simply cannot develop strong causal attributions with cross-sectional data, nor can they establish change, regardless of which analytical tools they use" (p. 657).

Panel data studies can better address causality issues. First, they can reflect the changes of innovation performance over time and reduce bias associated with idiosyncrasies of a particular period or economic cycles/shocks (Kafouros et al., 2008). Second, they can provide means to mitigate reverse causality, thereby strengthen the robustness of the inferences that can be made (Reeb et al., 2012). Third, if there are time-invariant effects across firms that are not captured in explanatory variables, 
but are correlated with the internationalization variable, panel data can purge such effects by accounting for time-specific effects, while studies using cross-sectional datasets are likely to reveal biased and inconsistent estimates of the effects (Görg $\&$ Strobl, 2001). Panel data however could increase the probability of making Type I errors, and lead to stronger statistical correlations between observations that are close to each other than those far part (Marano et al., 2016).

We thus expect a systematic difference in effect sizes in panel data studies and those of cross-sectional data studies. Over time, internationalized firms can better integrate the resources acquired, engage in organizational learning, build networks, enjoy localized spillovers, and gain synergy from internationalization and innovation strategies. As panel data tend to better capture cumulative effects (Dimos \& Pugh, 2016), we expect findings of stronger internationalization-innovation relationship in panel data studies than in cross-sectional data studies.

\section{Primary Data vs. Secondary Data}

The use of primary or secondary data is another source of heterogeneity in mixed research findings (Stanley \& Doucouliagos, 2012). Primary data may contain rich information providing questions that are carefully set. Secondary data, on the other hand, may not be based on questions that are directly related to research questions (Cowton, 1998). Primary data often relies on subjective views that reflect respondents' perceptions and therefore may not be objective. Perceptual measures are likely to be "broader" than objective measures and encompass more and different factors. This could affect the estimated effects of internationalization on innovation. In contrast, secondary data tends to contain objective information, but may not contain the depth and richness of primary data. Secondary data may present researchers with the temptation to arrive at more extensive conclusions than what the data would support (Harris, 2001).

Existing meta-analytical internationalization or innovation studies have shown that the effect sizes tend to have larger magnitude in primary studies employing perceptual measures than studies based on secondary data. For example, Beugelsdijk et al. (2018) found that the effect sizes associating perceptual measures of cultural distance to establishment mode, amount of knowledge that has been transferred or acquired, and performance are greater than other measurements (e.g., Kogut and Singh index). Zhao et al. (2017) reported that the effect size of the entry mode-performance relationship is statistically significantly larger in primary data than in secondary data. Bowen et al. (2010) revealed that after accounting for subjective measures of innovative posture (which facilitates innovative activities), the effect size of the innovation-performance relationship is greater. The possible reasons are managers tend to overestimate the internationalization and innovation of their activities (Beugelsdijk et al., 2018; Bowen et al., 2010) which are likely to be translated into their perceived corresponding effects. Respondents may overestimate the connection of attributes of business environments to internationalization, consequently, the role of internationalization may be overstated (Beugelsdijk et al., 2018).

We thus expect systematic differences in effect sizes, with the internationalization-innovation relationship being stronger in studies using primary data. 


\subsubsection{Statistical Artifacts}

\section{Estimation Methods}

Existing meta-analysis studies have shown that the use of different estimation methods as an important source of effect size heterogeneity. For example, Dimos and Pugh (2016), in their examination of the effectiveness of R\&D subsidies, reveal effect sizes differ between studies using propensity score matching (PSM) or difference-in-differences (DiD) modelling techniques. Yang and Driffield (2012) find that non-regression methods such as ANOVA methods or t-tests tend to have lower estimates for the linkage between multinationality/internationalization and performance. Appendix 1 reveals the methods in studies on the nexus, ranging from the conventional techniques of least squares (LS) including OLS and generalized least squares (GLS) and SEM to more sophisticated techniques of Bayesian analysis.

\section{Model Specifications}

To reconcile divergent results, existing studies have opted for more sophisticated functional forms by, for example, using non-linear equations for estimation. If the true functional form is non-linear, estimating linear functions can cause omitted variable bias as the omitted higher-order explanatory variables are correlated with errors. As a result, this leads to biased coefficient estimates, and more importantly, to faulty conclusions about theoretical propositions (Hamilton \& Nickerson, 2003).

\section{Endogeneity}

There are four major sources of endogeneity: measurement errors, simultaneity/ reverse causality, omitted variables and sample selection bias (Bascle, 2008; Hamilton \& Nickerson, 2003; Reeb et al., 2012). The first two have been discussed above. The third source of omitted variables is about model misspecification and refers to missing explanatory variables in estimated models. To establish causation, an essential condition is that no other causes should affect the relationship between dependent and independent variables (Bascle, 2008). However, if the dependent variable is affected by some unmodeled factors that could also drive other variables in the model, then endogeneity arises. Sample selection bias is associated with self-selection, i.e., whether the influence of internationalization on innovation is because firms self-select into engaging in internationalization. The techniques on addressing endogeneity include using lagged variables, adding many control variables, instrumental variables (IV) methods (e.g., 2SLS, 3SLS and GMM), Heckman two-step sample selection model and propensity matching model (Bascle, 2008; Hamilton \& Nickerson, 2003; Reeb et al., 2012). In panel data studies, unit-level (e.g., countrylevel, industry-level, firm-level, subsidiary-level) and time fixed effects are often controlled for to address the omitted variables issue.

On the internationalization-innovation nexus, attempting to address endogeneity is not a technical nicety, but an essential for increasing the prospects of obtaining unbiased estimates and, more importantly, testing the veracity of theories. Measurement errors and omitted variables may not be a severe issue in every empirical study however causality and sample selection bias are hard to rule out based on scrutinizing research context. Nevertheless, not all studies have sought to consider endogeneity. Possible reasons include difficulty in finding suitable instrumental variables, using 


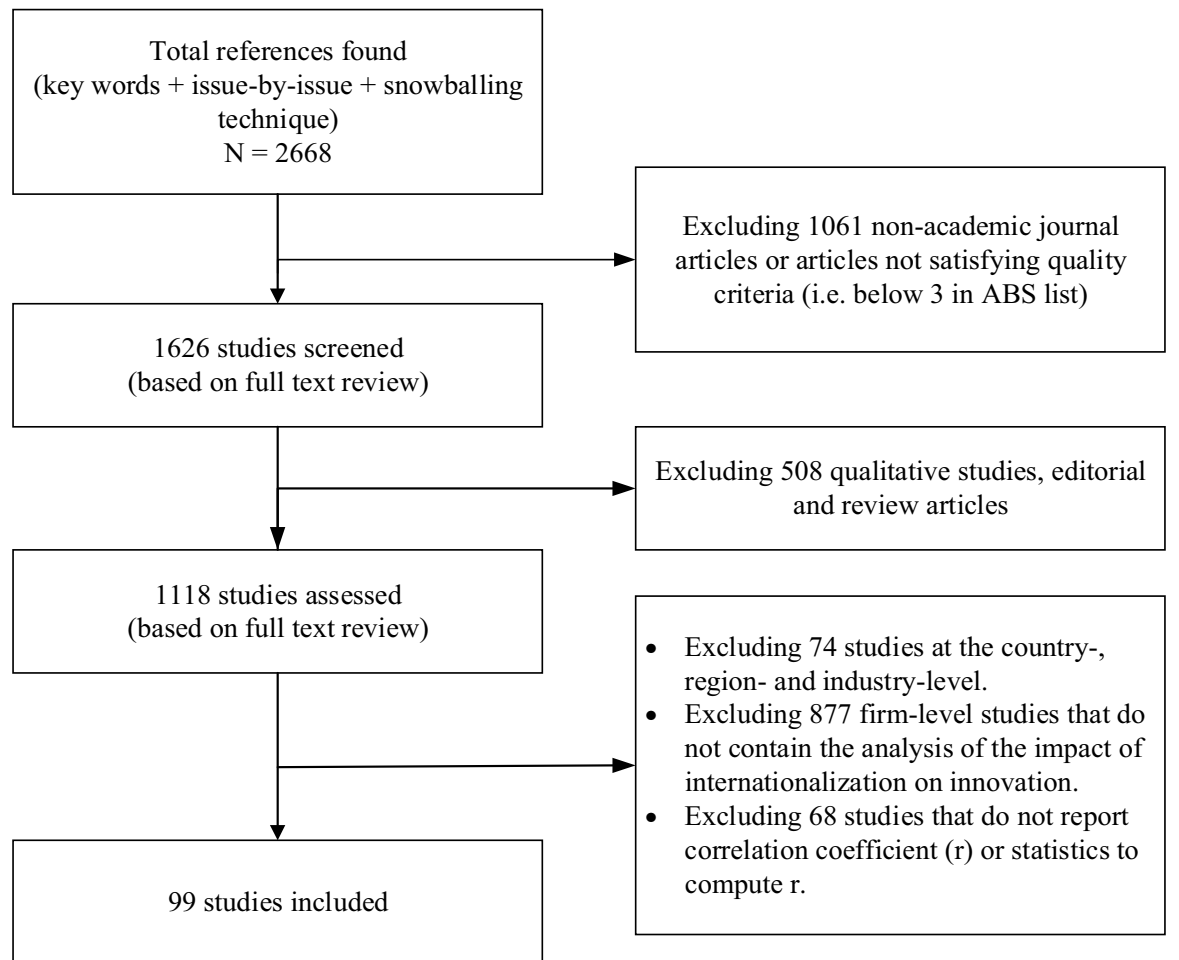

Fig. 1 Literature search and selection process of meta-analysis

cross-sectional datasets, and problems arising from econometric packages that do not provide the means to take account of endogeneity (Hamilton \& Nickerson, 2003).

\section{Methodology}

\subsection{Literature Search, Data Selection and Coding Procedure}

Collection of studies on the internationalization-innovation relationship followed the process illustrated in Fig. 1. A sequence of three search strategies identified the population of studies. First, seven electronic databases, ABI/Inform, Business Source Premier, EconLit, Google Scholar, Science Direct, JSTOR, and Web of Science were searched for studies published between January 1997 and April 2020. The year of 1997 was chosen because this was the publication date of the landmark article by Hitt et al. (1997). Search terms for the Internationalization construct included, internationalization, internationalisation, international diversification, international expansion, geographic diversification, multinationality, foreign operations, export, foreign direct investment, FDI, merger and acquisitions, merger and acquisition, $\mathrm{M}$ and $\mathrm{A}, \mathrm{M}$ and As, multinational enterprises, multinational corporations, foreign market entry and entry mode. For the Innovation construct terms comprised, 
innovation, $\mathrm{R}$ and $\mathrm{D}$, research and development and patent, together with "firms" thereby focusing on firm-level studies. Second, we manually searched top-tier journals, namely Journal of International Business Studies (JIBS), Academy of Management Journal (AMJ), Strategic Management Journal (SMJ), and Research Policy (RP). Finally, we utilized snowballing techniques to examine all references reported in previously identified studies. These search strategies yielded a collection of 2,668 potential papers.

Exclusion of studies was based on: (1) Only articles published in 3 or 4 rated journals according to the Chartered Association Business School (ABS) Academic Journal Guide 2018 to ensure high quality papers are included in the meta-analysis (Geng et al., 2017; Geyskens et al., 2009; Yang \& Driffield, 2012). This led to the exclusion of 1061 papers. (2) The selected articles used quantitative techniques, resulting in elimination of 508 qualitative studies, editorials and review articles. (3) Articles were firm or subsidiary level, resulting in exclusion 74 studies. As Beugelsdijk et al. (2010) point out, studies concentrated on the export and FDI at the industry, region or country level do not specifically capture firms' international value creation activities. (4) As the research focus is on the impact of internationalization on innovation performance, a further 877 firm-level studies were omitted because they had no analysis of the impact of internationalization on innovation. (5) Articles reported relevant sample statistics and effect sizes reported from separate sets of samples that had non-binary variables, so that they are comparable and capture a continuous effect (Stanley \& Doucouliagos, 2012). This last step excluded 68 papers. The final sample was therefore 99 studies.

The sample size was coded using the number of observations and the effect sizes on r-family statistics. For some studies, beta coefficients were transformed into correlation coefficients as recommended by Peterson and Brown (2005). This approach is consistent with most meta-analysis studies (e.g., Geyskens et al., 2009; Rosenbusch et al., 2019). As coding of the identified studies is critical for the quality of the meta-analysis, two authors coded independently and compared two separated coding forms. This led to $95 \%$ agreement between authors and remaining disagreements were revolved by discussions.

Appendix 1 presents the bibliographical details of the 99 articles. There are two interesting observations on the sample. First, $86 \%$ of publications appeared between 2008-2018, in contrast to only $14 \%$ between 1997-2007. Second, they are scattered in 36 ABS 3- or 4-rated journals, with RP being the leading outlet (14) followed by International Business Review (9), Journal of World Business (9) and JIBS (6). Appendix 2 presents the breakdown of these publications by research design factors. Clearly many more studies have used depth (83) than breadth (26) to measure firm internationalization. Innovation final outputs measures (50) are more popular than inputs measures (23) and intermediate outputs measures (33). As for data characteristics, 37 studies have used panel data, in contrast to 62 cross-sectional studies. Secondary data (60) are more popularly employed than primary data (39). In terms of the estimation methods, LS approaches are most common, followed by count and categorical modeling (21) and SEM (14). There is only one study each employing Bayesian and survival modeling approach. Regarding model specifications, most papers (86) focus on linear relationship and only 13 papers report the examination 
of non-linear association in the form of inverted U-shape (10), S-shape (3) and U-shape (1 paper). On endogeneity, in comparison to $57 \%$ of finance and economics studies that take account of this issue (Boyd \& Solarino, 2016), only $41 \%$ of studies in our meta-analysis have explicitly considered endogeneity. The approaches to address endogeneity include instrument variables (17), lagged variables (17), Heckman two-step sample selection model (9), fixed-effects specification (2) and negative binomial model with endogenous covariates (1).

\subsection{Meta-analytic Procedures}

We adopt the effect size as the unit of analysis. The number of effect sizes is consistent with Lipsey and Wilson (2001), relying on the minimum number of effect size.

$(k=3)$ consisting of at least 2 studies to limit the sensitivity of the previous results. The sample correlation coefficient $r$ is first transformed by Fisher's $z$ transformation to have approximately normally distributed statistical properties. A $95 \%$ $\mathrm{CI}$ is used to test whether the effect-size estimates are statistically significant. The within-group homogeneity statistic $Q_{w}$ that follows $\chi^{2}$-distribution with $k-1$ degrees of freedom is computed to examine whether the variability of the potential effect sizes is sufficiently interpreted by sampling error variance. A statistically significant $Q_{w}$ indicates the presence of potential moderators. We use the random-effects models to test the main effect sizes.

We further employ the meta-regression technique to examine the moderating effects (Geyskens et al., 2009). Meta-regression can investigate to what extent statistical heterogeneity among the results of multiple studies can be associated with one or more attributes of the studies. Table 2 provides a description of the moderator and control variables that are included in the meta-regression. The dependent variable is an estimate of the associational strength of the focal relationship in a given sample. We choose moderators related to research designs and control variables of country-of-origin, industry setting and firm size. The selection of control variables is constrained by available information from primary studies.

There are theoretical reasons to include country-of-origin. Firms in developed countries are more internationalized and conduct more innovation than those in developing countries. They tend to have more firm-specific assets and have better capability to sense, seize and transform resources acquired and/or developed through internationalization for innovation (Almeida \& Phene, 2004; Kirca et al., 2011). Their home country institutions are also supportive to innovation and offer infrastructure to help firms benefit from internationalization (Filiou \& Golesorkhi, 2016; Rosenbusch et al., 2019). Developing countries often have weak institutions, and also have more environmental uncertainties and learning difficulties compared to developed countries (Tang \& Gudergan, 2018). We thus expect country-of-origin to moderate the internationalization-innovation relationship, such that the relationship is stronger for developed country firms than for developing country firms.

Control for industry is necessary because differences in industrial structures are likely to affect the innovation by firms. High-tech industries tend to face more rapid and systematic technological changes than non-high-tech industries, hence firms in 
Table 2 Description of the variables

\begin{tabular}{|c|c|}
\hline Variable & Measure \\
\hline \multicolumn{2}{|l|}{ Moderator } \\
\hline Depth of internationalization & $\begin{array}{l}\text { A dummy variable, coded } 1 \text { for the depth of internationalization and } \\
0 \text { breadth of internationalization }\end{array}$ \\
\hline Innovation intermediate outputs & $\begin{array}{l}\text { A dummy variable, coded } 1 \text { for innovation intermediate outputs and } \\
0 \text { otherwise }\end{array}$ \\
\hline Innovation final outputs & $\begin{array}{l}\text { A dummy variable, coded } 1 \text { for innovation final outputs and } 0 \text { other- } \\
\text { wise }\end{array}$ \\
\hline Innovation outputs & $\begin{array}{l}\text { A dummy variable, coded } 1 \text { for innovation intermediate or final } \\
\text { outputs and } 0 \text { otherwise }\end{array}$ \\
\hline Panel data & $\begin{array}{l}\text { A dummy variable, coded } 1 \text { for longitudinal/panel data and } 0 \text { cross- } \\
\text { sectional data }\end{array}$ \\
\hline Primary data & A dummy variable, coded 1 for primary data and 0 secondary data \\
\hline SEM & $\begin{array}{l}\text { A dummy variable, coded } 1 \text { if structural equation modeling is } \\
\text { employed as a research method and } 0 \text { otherwise }\end{array}$ \\
\hline Bayesian and survival modeling & $\begin{array}{l}\text { A dummy variable, coded } 1 \text { if Bayesian or survival modeling is } \\
\text { employed as a research method and } 0 \text { otherwise }\end{array}$ \\
\hline Count and categorical modeling & $\begin{array}{l}\text { A dummy variable, coded } 1 \text { if count modeling (e.g., Poison, Negative } \\
\text { binomial) or categorical modeling (e.g., multinomial) is employed } \\
\text { as a research method and } 0 \text { otherwise }\end{array}$ \\
\hline Non-linear model & $\begin{array}{l}\text { A dummy variable, coded } 1 \text { for non-linear models and } 0 \text { linear- } \\
\text { models }\end{array}$ \\
\hline Endogeneity control & $\begin{array}{l}\text { A dummy variable, coded } 1 \text { if the estimation accounted for endoge- } \\
\text { neity and } 0 \text { if not }\end{array}$ \\
\hline \multicolumn{2}{|l|}{ Control variable } \\
\hline Developed country & $\begin{array}{l}\text { A dummy variable, coded } 1 \text { if country-of-origin is a developed coun- } \\
\text { try and } 0 \text { otherwise }\end{array}$ \\
\hline High-tech manufacturing & $\begin{array}{l}\text { A dummy variable, coded } 1 \text { if the industry setting is high-tech manu- } \\
\text { facturing and } 0 \text { otherwise }\end{array}$ \\
\hline Large firms & A dummy variable, coded 1 if firms are large firms and 0 otherwise \\
\hline SMEs & $\begin{array}{l}\text { A dummy variable, coded } 1 \text { if firms are small and medium-sized } \\
\text { firms and } 0 \text { otherwise }\end{array}$ \\
\hline
\end{tabular}

such turbulent environments are usually more innovative (Kirca et al., 2011; Rousseau et al., 2016). However, knowledge involved in these firms is usually of tacit and complex nature, consequently, cannot be easily learnt and/or exploited to create value (Hashai, 2018; Xia \& Liu, 2017). As a result, we posit firms in high-tech industries to benefit less from internationalization for innovation than their counterparts in non-high-tech industries.

We also control for firm size differentiating large firms from non-large firms, including small and medium-sized enterprises (SMEs) and mixed group samples. This enables the consideration of moderating effects of differences in resource availability (financial, management and information). Large firms are usually resource abundant, allowing them to bear fixed costs and take on greater risks associated with both internationalization and innovation (Geldres-Weiss et al., 2016; Gkypali et al., 
2018; Hitt et al., 1997). Increased size also makes it easier for firms to better utilize global resources for innovation and enhances potential returns to innovation through leveraging resources acquired or developed from international activities (Bausch \& Krist, 2007; Camisón-Zornoza et al., 2004). Consequently, we predict the internationalization-innovation relationship to be stronger for large firms than non-large firms and to be weaker for SMEs than non-SMEs.

Finally, it has been argued that editors, reviewers and academic journals have a tendency to accept articles with "statistically significant results" (Stanley \& Doucouliagos, 2012). This may entice scholars selecting samples, functional forms, estimation techniques and control variables to maximize the prospects of obtaining significant results. To test for publication bias, we use $p$-value criterion. Egger's test is used to check replicability and reliability of results.

\section{Results}

Tables 3 reports the main effect results. At the aggregated level, there is a positive and statistically significant relationship between internationalization and firm innovation $\left[M_{r}=0.114\right.$, CI $\left.(0.101,0.126)\right]$. This finding supports the positive effects of internationalization on innovation, albeit the magnitude is small. Cohen (1988) suggests the thresholds for interpreting effect size being $0.1,0.3$, and 0.5 for small, medium, and large effect size, respectively. Similar small effect sizes have been found in meta-analysis studies on the relationship between internationalization and firm's financial and market performance with $M_{r}$ taking the values of $0.059,0.10$ and 0.06 in Bausch and Krist (2007), Kirca et al. (2011) and Marano et al. (2016), respectively. Our evidence is also comparable to that reported by Rosenbusch et al. (2019) in their study of the impact of $R \& D$ internationalization on innovation $\left[M_{r}=0.145, C I(0.115,0.176)\right]$. As the $95 \%$ CIs overlap, we cannot tell whether the effect sizes are statistically different. We also separated our sample into two groups: studies that clearly identify R\&D internationalization and those that do not specify that type of internationalization (i.e., internationalization may be through R\&D, manufacturing and/or sales). The results again confirm the positive, albeit small effects of internationalization in both samples $\left[M_{r}=0.092, C I(0.022,0.163)\right.$ for the former group; $M_{r}=0.116, C I(0.103,0.130)$ for the latter group]. The $95 \% \mathrm{CIs}$ again overlap with that of the whole sample and that of Rosenbusch et al. (2019).

Consideration of the results reveals some different effect sizes according to the type of internationalization (depth and breadth) and different stage of innovation measures (inputs, intermediate outputs and final outputs). The findings for depth of internationalization are consistent with those at the aggregate level. The impact of the breadth of internationalization on innovation measured by intermediate outputs is, however, statistically insignificance. Comparing the mean effect sizes, the effects of depth $\left[M_{r}=0.131, C I(0.116,0.146)\right]$ is greater than those of breadth of internationalization $\left[M_{r}=0.068, C I(0.040,0.097)\right]$. As the two $95 \%$ CIs do not overlap, there is a statistically significant difference between the two effect sizes. Depth appears to have greatest effects on innovation intermediate 


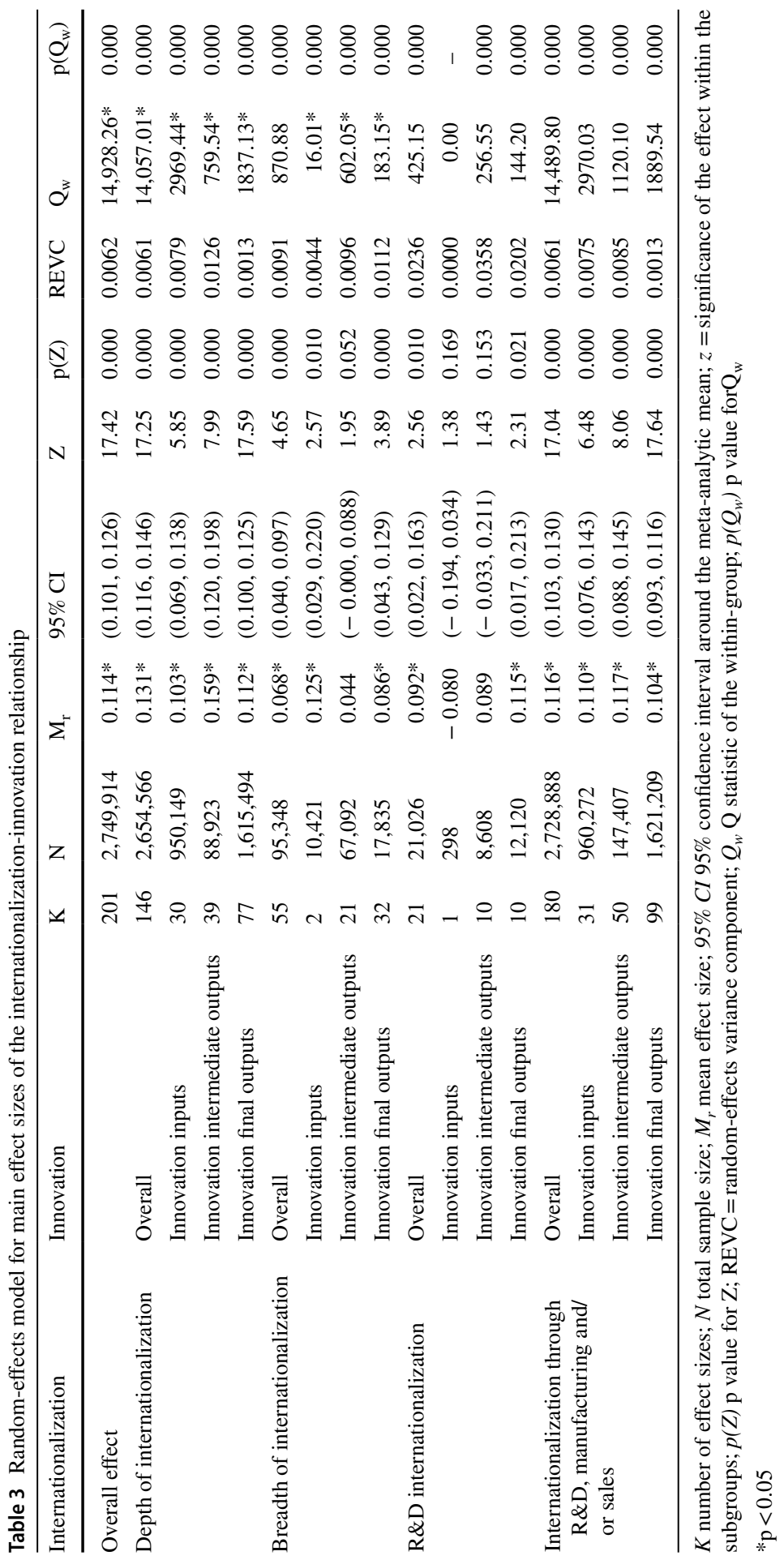


outputs $\left[M_{r}=0.159, C I(0.120,0.198)\right]$, followed by innovation final outputs $\left[M_{r}=0.112, C I(0.100,0.125)\right]$, then innovation inputs $\left[M_{r}=0.103, C I(0.069\right.$, 0.138)]. However, as the three $95 \%$ CIs overlap, we cannot tell whether the effect sizes are statistically different. The effects of breadth are limited to innovation final outputs $\left[M_{r}=0.086, C I(0.043,0.129)\right]$ and innovation inputs $\left[M_{r}=0.125\right.$, $C I(0.029,0.220)]$. It is interesting that $\mathrm{R} \& \mathrm{D}$ internationalization only significantly influences innovation final outputs $\left[M_{r}=0.115, C I(0.017,0.213)\right]$.

In our sample, most studies (72) were based on a single country. In total 21 single countries were examined. The countries most often studied were the US, China, Sweden, Taiwan, and Spain. Table 4 shows the country-specific randomeffects model results. Those based on a quite small number of effect sizes $(k \leq 3)$ (i.e., Brazil, Germany, Israel, Italy, and Portugal) should be interpreted with caution. Table 4 reveals that national differences in the magnitude, strength, and direction of the focal association are substantial. The focal relationship is statistically significant in most countries (15 out of 21 countries), except for Taiwan. Among those significant results, the focal relationship is the strongest in Australia $\left[M_{r}=0.650, C I(0.537,0.764)\right]$ and the weakest in Ireland $\left[M_{r}=0.059, C I(0.029\right.$, $0.089)]$. Along the spectrum, the effect size is small $\left(M_{r}<0.1\right)$ in the context of Ireland, Spain, China, and Switzerland; whereas it is large in Australia $\left(M_{r}>0.5\right)$. In between, most countries see small effects $\left(0.1<M_{r}<0.3\right)$ apart from Chile with medium effects $\left(0.3<M_{r}<0.5\right)$. This mixed set of results raises the question of generalizability of findings from single-country studies. Additionally, a statistically significant $Q$-statistic in Table 3 and mixed results in Table 4 indicate the presence of potential factors that may confound causal inferences. We proceed with meta-regression analysis to detect the role of research design factors.

Table 5 displays the meta-regression results. For ease of interpretation, the findings are summarized in Table 6. Model 1 includes only control variables. Model 2 adds the variable Depth of internationalization. The meta-regression analysis confirms that internationalization measurements influence the effect size of the focal relationship, indicating that different dimension of internationalization generates different level of benefits to innovation performance. Models 3 and 4 add innovation measures to Model 1. In model 3, both Innovation intermediate outputs and Innovation final outputs are statistically insignificant. In model 4, we combine intermediate outputs and final outputs measures to create a new dummy variable, Innovation outputs. But again, this variable is statistically insignificant.

Model 5 adds variables related to data characteristics. Panel data is significant, while Primary data is insignificant, indicating that data characteristics, particularly panel data, influence the results. However, the direction of impact is different from our expectation. As Görg and Strobl (2001, p. F738) noted, the higher estimates in cross-sectional studies could be due to such data structure not allowing for "other time-invariant firm or sector specific effects, which may impact on the [focal] relationship, but for which the researcher does not have any information".

Model 6 adds variables related to statistical artefacts including different estimation methods, model specification and attempts at endogeneity control. The focal relationship in studies employing SEM differs significantly from those employing least squares modeling, but that effect sizes in studies employing other estimation 
Table 4 Country-specific results of random-effects model

\begin{tabular}{|c|c|c|c|c|c|c|c|c|c|}
\hline Country & $\mathrm{k}$ & $\mathrm{N}$ & $\mathrm{M}_{\mathrm{r}}$ & $95 \% \mathrm{CI}$ & $\mathrm{Z}$ & $\mathrm{p}(\mathrm{Z})$ & REVC & $\mathrm{Q}_{\mathrm{w}}$ & $\mathrm{p}\left(\mathrm{Q}_{\mathrm{w}}\right)$ \\
\hline Australia & 1 & 302 & $0.650 *$ & $(0.537,0.764)$ & 11.25 & 0.000 & 0.0000 & 0.00 & - \\
\hline Brazil & 1 & 202 & 0.080 & $\begin{array}{c}(-0.059 \\
0.219)\end{array}$ & 1.13 & 0.258 & 0.0000 & 0.00 & - \\
\hline Chile & 3 & 138 & $0.454 *$ & $(0.228,0.680)$ & 3.94 & 0.000 & 0.0167 & 3.43 & 0.180 \\
\hline China & 35 & $2,397,788$ & $0.079 *$ & $(0.055,0.103)$ & 6.33 & 0.000 & 0.0042 & $8436.53 *$ & 0.000 \\
\hline Germany & 2 & 8775 & 0.054 & $(-0.153,0.261)$ & 0.51 & 0.611 & 0.0218 & $41.04 *$ & 0.000 \\
\hline Ghana & 2 & 328 & $0.245^{*}$ & $(0.136,0.354)$ & 4.40 & 0.000 & 0.0000 & 0.33 & 0.568 \\
\hline Greece & 7 & 1427 & $0.293^{*}$ & $(0.149,0.438)$ & 3.97 & 0.000 & 0.0328 & $44.89 *$ & 0.000 \\
\hline India & 4 & 62,064 & $0.117 *$ & $(0.057,0.178)$ & 3.79 & 0.000 & 0.0036 & $73.00 *$ & 0.000 \\
\hline Ireland & 2 & 4213 & $0.059 *$ & $(0.029,0.089)$ & 3.83 & 0.000 & 0.0000 & 0.03 & 0.855 \\
\hline Israel & 3 & 962 & -0.010 & $(-0.212,0.193)$ & 0.09 & 0.926 & 0.0254 & $10.55^{*}$ & 0.005 \\
\hline Italy & 1 & 84 & 0.110 & $(-0.107,0.328)$ & 0.99 & 0.320 & 0.0000 & 0.00 & - \\
\hline Japan & 6 & 1665 & $0.163 *$ & $(0.068,0.257)$ & 3.36 & 0.001 & 0.0097 & $17.80 *$ & 0.003 \\
\hline Netherlands & 3 & 2438 & $0.150 *$ & $(0.059,0.241)$ & 3.23 & 0.001 & 0.0034 & 4.12 & 0.128 \\
\hline Pakistan & 2 & 497 & $0.110 *$ & $(0.097,0.122)$ & 0.26 & 0.793 & 0.2344 & $42.78^{*}$ & 0.000 \\
\hline Portugal & 3 & 1557 & 0.149 & $\begin{array}{c}(-0.316 \\
0.613)\end{array}$ & 0.63 & 0.530 & 0.1665 & $173.86^{*}$ & 0.000 \\
\hline Spain & 9 & 52,008 & $0.070 *$ & $(0.028,0.112)$ & 3.28 & 0.001 & 0.0039 & $183.05^{*}$ & 0.000 \\
\hline Sweden & 12 & 1924 & $0.189 *$ & $(0.084,0.295)$ & 3.51 & 0.000 & 0.0283 & $59.78^{*}$ & 0.000 \\
\hline Switzerland & 2 & 5346 & $0.087 *$ & $(0.060,0.113)$ & 6.32 & 0.000 & 0.0000 & 0.22 & 0.639 \\
\hline Taiwan (China) & 12 & 41,368 & 0.058 & $\begin{array}{c}(-0.001 \\
0.118)\end{array}$ & 1.92 & 0.055 & 0.0101 & $375.58 *$ & 0.000 \\
\hline $\begin{array}{l}\text { United King- } \\
\text { dom }\end{array}$ & 6 & 5257 & $0.117 *$ & $(0.060,0.175)$ & 4.02 & 0.000 & 0.0039 & $21.83 *$ & 0.001 \\
\hline United States & 40 & 26,444 & $0.134 *$ & $(0.085,0.183)$ & 5.31 & 0.000 & 0.0226 & $567.31^{*}$ & 0.000 \\
\hline Mixed & 45 & 135,127 & $0.111^{*}$ & $(0.062,0.160)$ & 4.46 & 0.000 & 0.0249 & $2570.80^{*}$ & 0.000 \\
\hline
\end{tabular}

$* p<0.05$

See Table 3

methods including Bayesian and survival modeling, and count and categorical modeling do not seem to be statistically different from those using least squares modeling. The strength of the focal relationship also does not differ between studies using linear and those using non-linear models. Seeking to address endogeneity seems however to be an important issue.

Model 7 includes all moderators and control variables. The results remain consistent with those when different types of moderators are separately considered, except that Panel data becomes statistically insignificant. This might be because panel data effects are picked up by attempts at endogeneity control. In Model 8, we also check whether publication outlet is an underlying moderator. The meta-regression presents a statistically insignificant coefficient $\left(b=-0.0230, S E_{b}=0.0290\right)$. Model 9 adds an additional control variable, $S M E s$, to check robustness. This additional control is not statistically significant, and the findings of Model 8 and Model 9 are similar. 


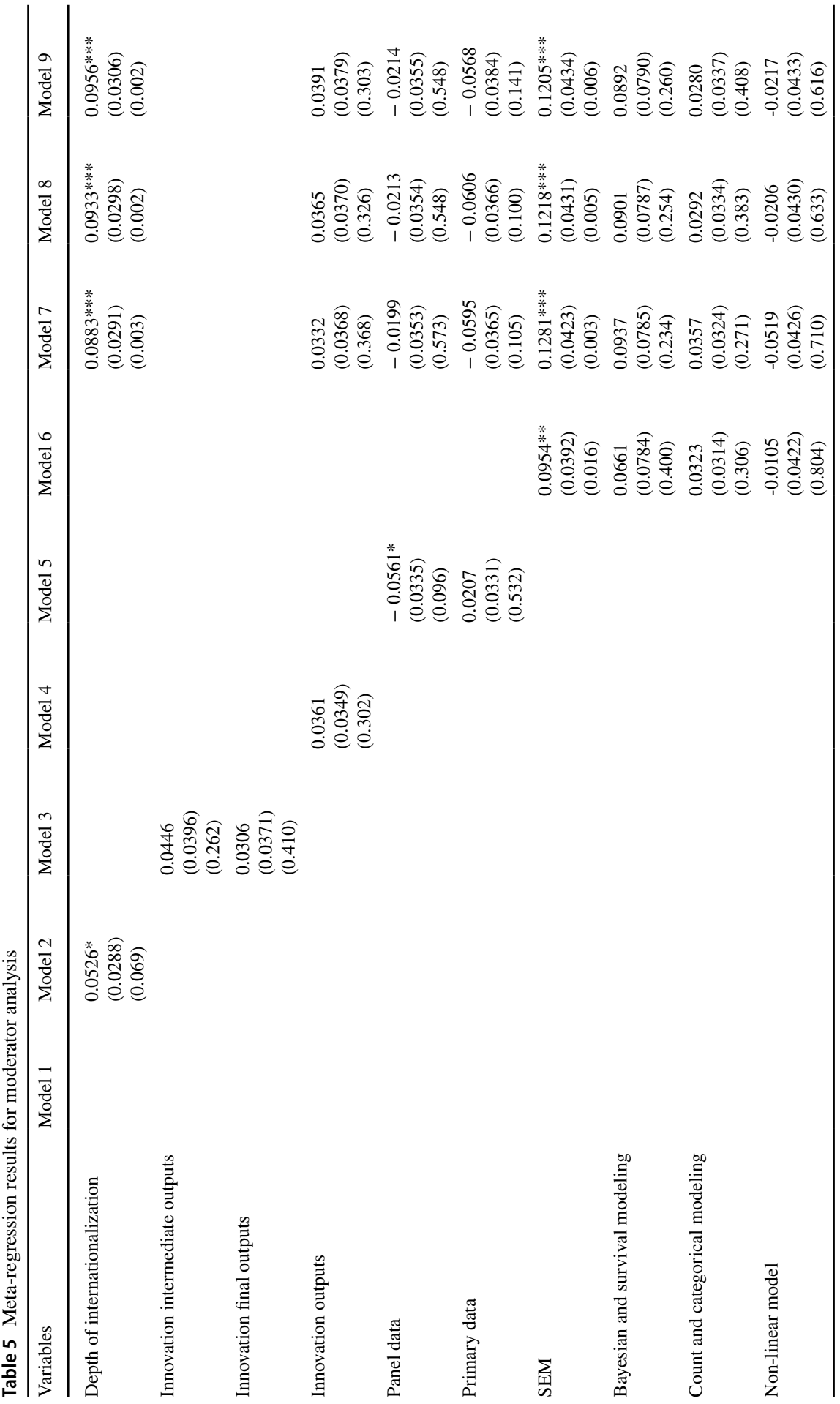




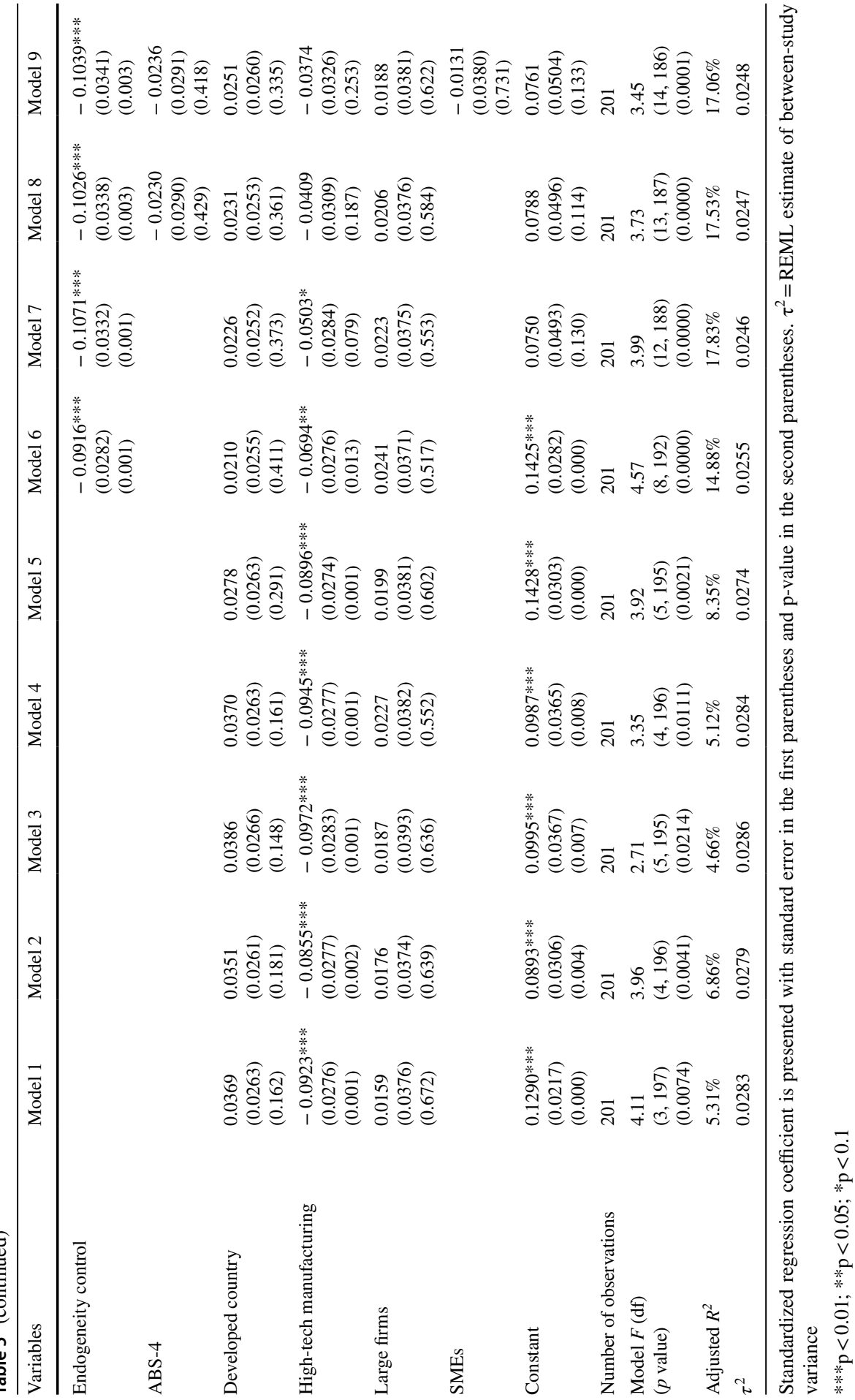


Robustness checks included replacing Depth of internationalization with dummy variables for FDI measures and Export measures and a dummy variable to capture multi-dimensional measures of internationalization. Neither of these dummies are statistically significant and results for other variables remain intact. We replaced Depth of internationalization with the variable $R \& D$ internationalization in Models 2, 7, 8, and 9 and added $R \& D$ internationalization to Models 7,8 , and $9 . R \& D$ internationalization is statistically insignificant in all models and results for other variables remain qualitatively similar to those in Models 2, 7, 8, 9. We have also identified those studies that have employed PLS-SEM methods and the dummy variables that capture PLS-SEM and non-PLS-SEM are statistically significant in Models 7, 8, and 9, while the results for other variables remain unchanged. Finally, we repeated the meta-regression analysis for four subsamples: (1) sample excluding studies of the US; (2) sample excluding studies of China; (3) sample excluding mixed countries studies; (4) samples excluding all three country/countries groups, i.e., the US, China and mixed countries. Results for the first two subsamples are very similar to those of Table 5. For the subsample (3), the findings remain approximately the same except that Depth of internationalization, albeit with the positive coefficient, has become statistically insignificant and Primary data has become statistically significant. The sample size for subsample (4) reduces substantially from 201 to 81. The results are slightly more different from those of Table 5. Depth of internationalization is again statistically insignificant. Innovation intermediate outputs now becomes statistically significant. In contrast, SEM has become statistically insignificant which might be because only a small number of studies in this subsample (6 in total) employed SEM. Overall, the results are fairly robust. ${ }^{1}$

Model 8 reports that around $18 \%$ (adjusted- $R^{2}$ ) of the between-study variance is explained by the research-design covariates. The remaining between-study variance $\left(\tau^{2}\right)$ seems small. Thus, a combination of research design factors explains a significant proportion of the variance of effect sizes. Finally, we examine publication bias. The results show that it is not a serious issue in our meta-analysis data pool. ${ }^{2}$

\section{Discussion and Conclusions}

\subsection{Theory Contribution}

Our findings support the view that internationalization has small but positive effects on firm innovation. Consideration of key contextual factors improves the size effects of the estimates, suggesting that good research design should identify and analyze how major contextual factors affect various causal paths that emerge from the variety of theoretical approaches used to examine the nexus. The importance of addressing contextual issues has been advocated in International Business research (Kostova \& Hult, 2016; Ma et al., 2016; Slangen \& Beugelsdijk, 2010) and our study reinforces the case for a greater focus on these issues. An example of how KBV

\footnotetext{
1 The results for these robustness checks are not presented but available upon request.

2 The results are not presented but available upon request.
} 
Table 6 The internationalization-innovation nexus: a summary of evidence

\begin{tabular}{ll}
\hline Key perspectives $\quad$ Findings from meta-regressions \\
\hline
\end{tabular}

Type of internationalization (depth and breadth)

Different dimension of internationalization generates different level of benefits to innovation performance, with the depth of internationalization having greater size effects than the breadth of internationalization

Stage of innovation (inputs, intermediate outputs and final outputs)

Panel data vs. cross-sectional data

Primary data vs. secondary data

Estimation methods: SEM vs. least square modelling

Estimation methods: Bayesian and survival modeling/count and categorical modeling vs. Least square modelling

Model specifications: Non-linear model vs. linear model

Endogeneity

Developed countries vs. developing countries

High-tech manufacturing vs. industries not specified

Firm size
How innovation is measured by stage does not affect the effect sizes of the focal relationship

In comparison to studies that employ cross-sectional data, those that use panel data tend to find smaller effect sizes of the focal relationship

Effect sizes of the focal relationship in studies employing primary data and those employing secondary data do not tend to be significantly different

Effect sizes of the focal relationship in studies employing structural equation modeling (SEM) tend to be significantly larger than those employing Least squares modeling

Effect sizes of the focal relationship in studies employing other estimation methods including Bayesian and survival modeling and count and categorical modeling do not seem to be statistically different from those using Least squares modeling

The strength of the focal relationship does not tend to differ between studies using linear and those using non-linear models

Effect sizes of the focal relationship in studies controlling for endogeneity tend to be significantly smaller than those not controlling for endogeneity

The strength of the focal relationship does not tend to differ between studies of developed countries group and those of developing countries group

Effect sizes of the internationalization and innovation relationship in studies focusing on high-tech manufacturing tend to be significantly smaller than those not exclusively focusing on high-tech manufacturing

The effect sizes of the internationalization and innovation relationship do not tend to differ between studies of different firm sizes

might be developed to better account for major contextual factors is provided in Fig. 2. The method suggested could be used as a guide to how other causal chains from other theoretical approaches could be developed to better address major contextual issues. 
Comparing the effects of depth and breadth of internationalization, the results highlight that depth is more strongly associated with firm innovation than breadth. This is in contrast to findings of meta-analytics studies by Kirca et al. (2012) and Marano et al. (2016) that reveal breadth of internationalization having a stronger effect on firm performance than depth. The reason may be, although depth allows firms to achieve economies of scale and scope, breadth provides arbitrage operations across different locations that enable the diversification of risks and thereby secure better financial or market performance. Depth is also often required to effectively integrate acquired knowledge and resources in organizational learning and in securing benefits from business networks. Breadth maybe be an important factor in causal chains based on organizational learning, network theories, and spillover approaches due to the wider range of knowledge that is available from wide-ranging internationalization. It is possible that different combinations of depth and breadth have a variety of effects depending on the nature of the causal chains that are used to examined topics in the nexus. To resolve this issue requires careful conceptualization of the role of contextual issues connected to the type of internationalization to arrive at robust estimates. Such conceptualization would also help to better define the boundaries of the postulated relationships. Regardless of the theoretical approach and causal chains used, our results suggest that consideration of the type of internationalization is likely to be important to obtain good estimates.

Internationalization (both depth or breath) appears to have effects on innovation when inputs and final outputs measures are employed. The findings however reveal that only depth is connected to innovation intermediate outputs. There are studies on the effects of breadth and depth of internationalization on the relations between knowledge stock and overall performance of firms (e.g., Kafouros et al., 2012) and breadth of internationalization and innovation on firm performance (e.g., Kafouros $\&$ Buckley, 2008). To our knowledge however there are no studies that explicitly consider the effects of different dimensions of internationalization on the various stages of innovation. Theoretical approaches use an array of postulated causal chains to examine links between internationalization and innovation. There is therefore a need to address the often-complex contextual issues that may influence the type of innovation that relates to postulated causal chains. If such studies are rigorously conceptualized and operationalized, the resulted estimates of the effect size should be more robust.

The findings reveal different outcomes between single-country studies and multi-countries studies thereby underlining the importance of country context. The mean effect sizes are small to large. Single-country research design plays a dominant role in the existing studies. In principle, single country studies can provide deep and rich information thereby offering opportunities to evaluate whether a given theory performs as expected (Hotho et al., 2015). This use of single or small numbers of homogenous countries however raise concerns due to generalizing from restricted samples that are seeking to represent heterogenous locations (Coviello $\&$ Jones, 2004). The heterogenous nature of conditions in host locations implies 
that a multitude of internationalization and innovation strategies are likely to affect the association between internationalization and innovation in different countries. This suggests that single country or groups of similar countries may provide high quality results that are valid and robust but are only valid for the countries studied. Such studies however provide the basis for unpacking the generic picture from multi-country studies to highlight where significant and large benefits are available. This type of approach should be done for any causal chain that can be identified as likely to be affected by country conditions. This would help to better understand the geographical dispersion of innovation activities and why despite evidence that, in general, the benefits appear to be small, the volume and intensity of the internationalization process appears to be growing. Consideration of the effect of country context would therefore help to provide more robust estimates and to clarify boundary conditions for causal paths.

\subsection{Empirical Methods Contribution}

The results shed light on how variation in effect sizes can be explained by variable measurements, data characteristics and statistical artifacts. One major issue raised by the results is about the conceptualization and measurements of internationalization and innovation. More attention is required to clarify the key conceptual definitions of internationalization processes and innovation stages and refining theory based on this to provide hypotheses to be tested. Another key finding is the use of panel data and SEM. Issues connected to causality cannot be identified by this study. Future research design may, however, consider using more advanced techniques to develop knowledge on causality to tackle this problem. Attempts to address endogeneity in general has the potential to improve evidence on causal paths in the internationalization-innovation nexus. Thus, refining theory that is tested using appropriate cutting-edge data gathering, processing and analysis could shed light on the size effects in the nexus.

Another key requirement area for empirical research design is the country context of studies. Future research should be framed to help to fine-tune understanding in single-country studies by highlighting key factors that influence the relationship between internationalization and innovation for the countries that are studied. Future research should also pay attention to the research designs of diverse countries that would permit the systematic comparison of the differences and similarities between country groupings by geographical area, level of economic development etc. Findings of this kind would enable a better understanding of country contexts that could help to develop theoretical and policy perspectives on the relationship between internationalization and innovation.

\subsection{Practical Implications}

The findings provide some insights for managers and policymakers. Firms and public policymakers need to assess the evidence for the net benefits found in studies in the light of the risk of adopting inappropriate internationalization because of failure 


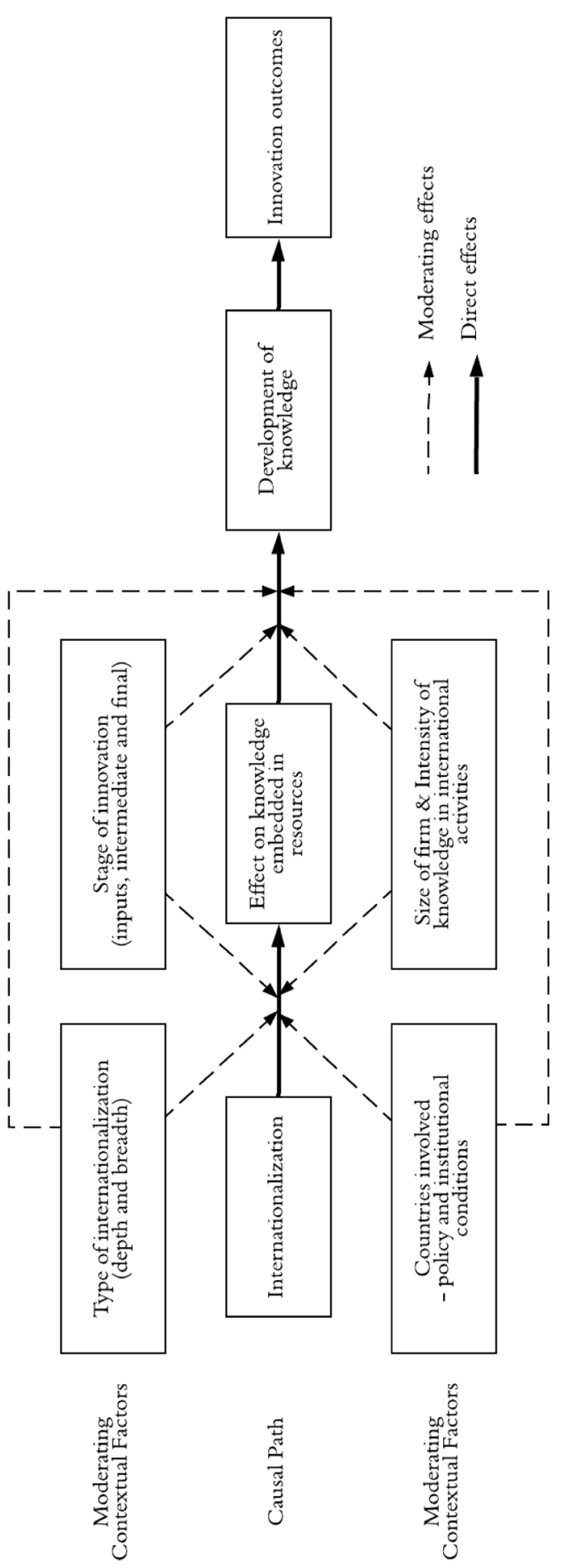

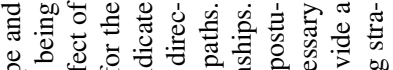

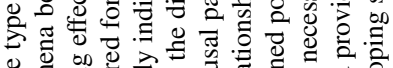
\&

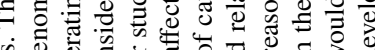

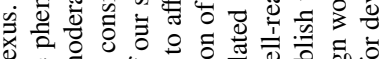

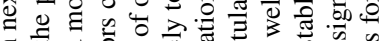

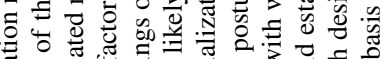

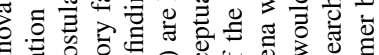

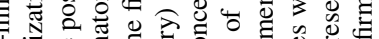

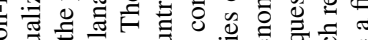

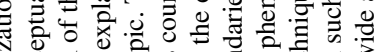

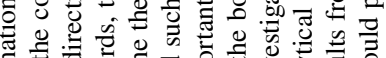

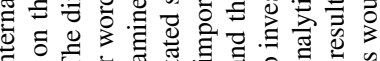

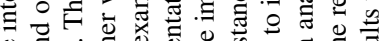

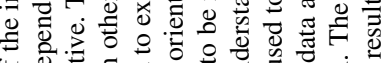

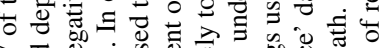

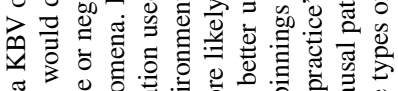
\%

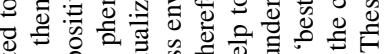

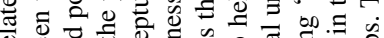

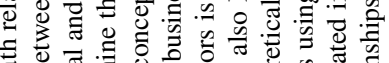

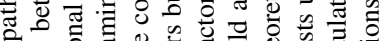

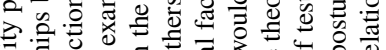
牙

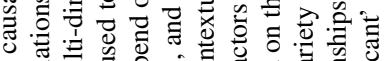

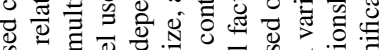

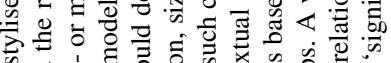

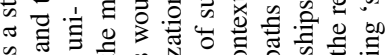

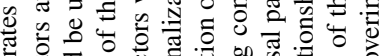

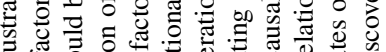

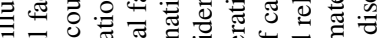

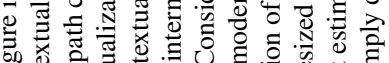
不 ฮ

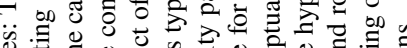

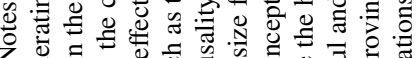

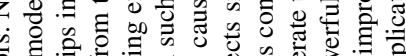

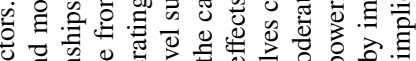

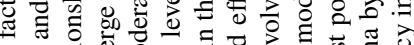

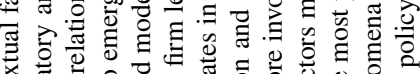

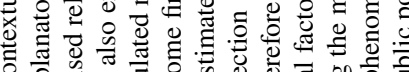

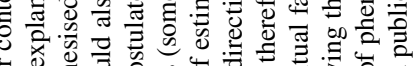
它论

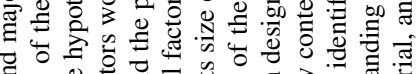

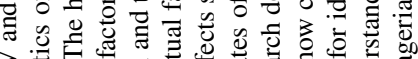

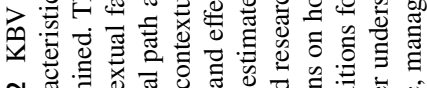

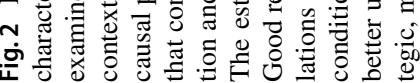


to adequality account for the effects of key contextual factors and from shortcomings in data measurement and analysis. The mostly small to moderate effect sizes found in our study suggest it is important that private and public policymakers check results to ascertain if key contextual factors are included in studies. This would help to identify the boundaries of where the postulated effects are applicable. This would reduce the risk of making inappropriate strategic, managerial decisions and in public policymaking that arises from using results that do not apply to the contexts faced by decision-makers. Our suggestions for future research indicate some of the areas where more knowledge is needed to improve the basis for better understanding of the strategic, managerial decisions and public policy implications associated with internationalization and innovation. This information may also be of value for managers and policymakers that commission research on aspects of the nexus. Our results also highlight the wisdom of checking the rigor of the data analysis techniques used in research to ensure that best practice is used to seek to reduce errors associated with inappropriate data measurement and analysis that undermine the value of results.

\subsection{Future Research Directions}

The findings on the importance of contextual issues and of addressing key data analysis techniques imply that future studies that consider these issues could provide improved evidence that could enrich theory development to help to better understand relationships within the nexus. This would provide better guidance to private and public policymakers. The focus on research design should be applied to causal chains emerging from the various theoretical approaches used to examine the nexus. The results suggest that developed theoretical frameworks are likely to be required to address complex issues about how contextual factors affect causal chains. This could include the possibility of multi-directional causal relationships within the nexus. The resultant causal chains need to be rigorously tested to determine the direction of causation and the importance of contextual factors for effect size. This would provide more accurate estimates and would enable better identification of the boundaries of the postulated relationships. These estimates would also need to address key data and analytical issues. Resolving these issues is challenging but the findings of this study indicate the importance of addressing them in order to ensure the robustness of results.

Investigating the potency of the estimates of internationalization for innovation for the numerous causal chains from a variety of theoretical approaches would be useful. The techniques for such work, such as meta-analytic structural equation modeling (MASEM), have been developed (Bergh et al., 2016). Analysis of this kind requires identification of suitable studies which have clearly identified theoretical 
underpinnings and have been operationalized in a way that provides distinct estimates of the relationships postulated in causal chains. Unfortunately, there are few studies published in high quality journals that provide such information. This currently makes it difficult to assess the robustness of estimates from different theoretical approaches and from different causal chains using the same theoretical approach (Steel et al., 2021). Future research therefore needs to provide clear indications of the theoretical approach, causal relationships that are used, the contextual factors that are considered and how they relate to the postulated causal chains. This would help to provide robust evidence that could be used to develop the theoretical approaches to better understand how the nexus works. This is a challenging research agenda, but it holds the prospects of enhanced understanding of the nexus that would help to devise more useful strategic, managerial and policy implications.

\subsection{Limitations}

There are several limitations in the study. A meta-analysis can only be as good as the papers sampled (Geyskens et al., 2009). For this reason, we focused on articles from journals considered to be high quality by the CABS Journal Quality Guide which is produced "based upon peer review, editorial and expert judgement on the quality of journals in which business and management academics publish their research" (Geng et al., 2017, pp. 247-248) and has been used by researchers to identify quality papers in systematic literature review (e.g., Geng et al., 2017; Yang \& Driffield, 2012). There may be some relevant, high-quality, and important research outside of these journals. There are however a large number of such journals and many of the papers have low citations so are unlikely to have a significant impact on the research community and the development of theory.

Although our investigation on different aspects of internationalization and innovation helps to expand knowledge about the nexus, other aspects may deserve future attention. For example, our study only considers the concept of innovation in terms of inputs or outputs. Innovation can also be conceptualized by degree (disruptive, radical, or incremental), type (process, product, service or business model) and function (technological and non-technological). Studies using these sorts of ideas of innovation are currently not many, preventing us from incorporating this into our meta-analysis. Similarly, the low number of studies on the speed internationalization led to this not being considered in the current paper. Albeit these limitations, this study provides a starting point for developing the research design of empirical studies that could enrich the literature on the internationalization-innovation relationship. 


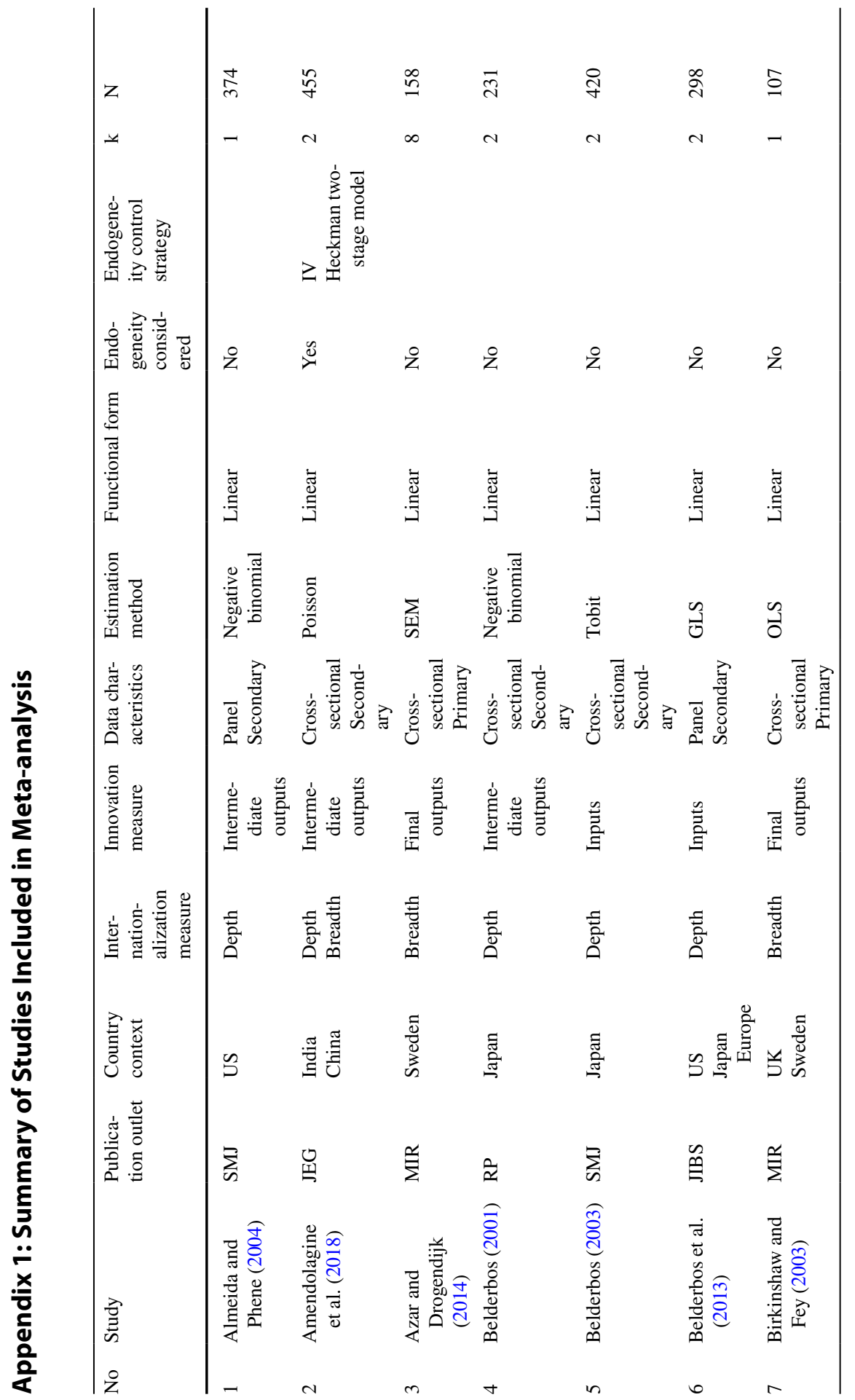




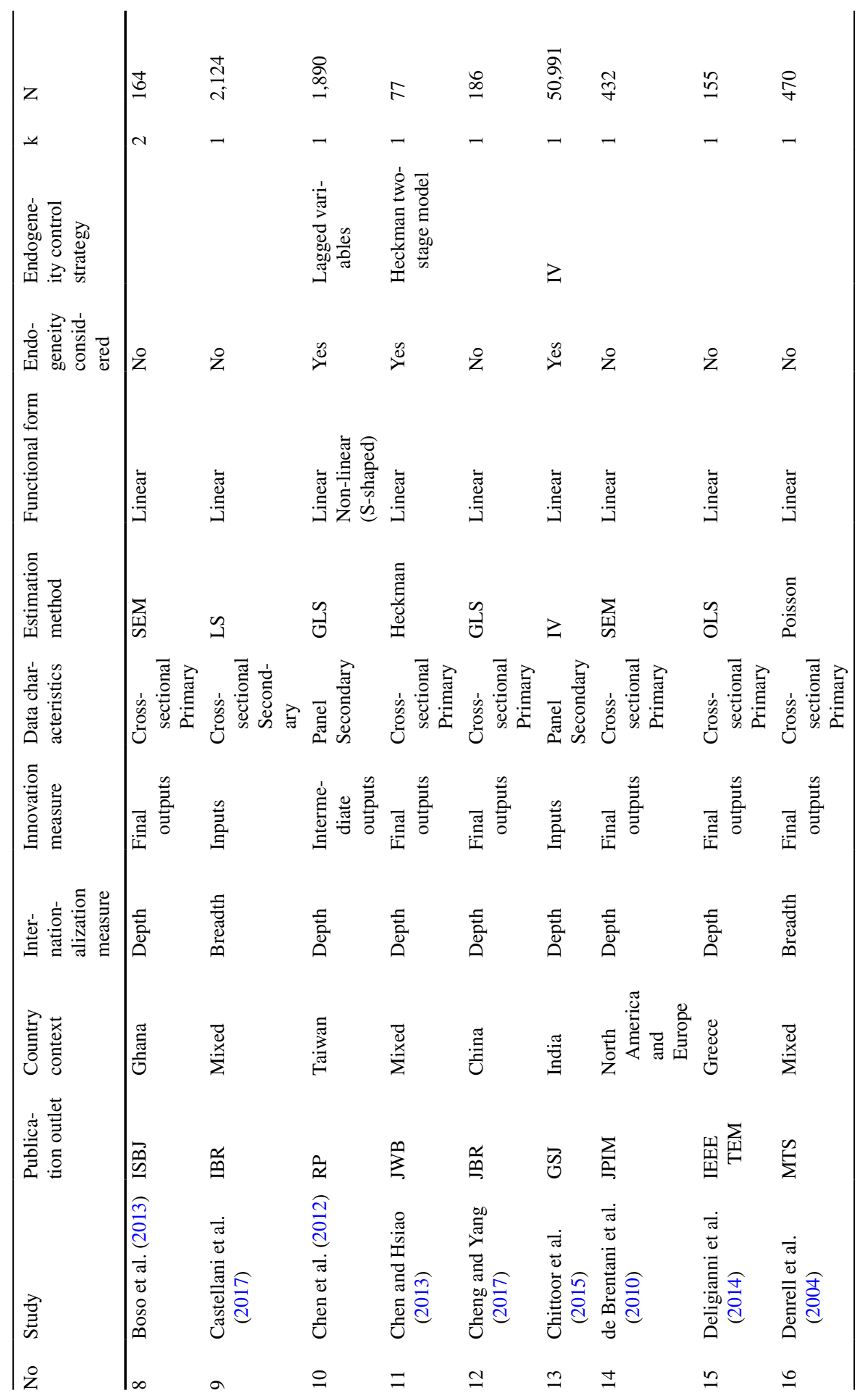




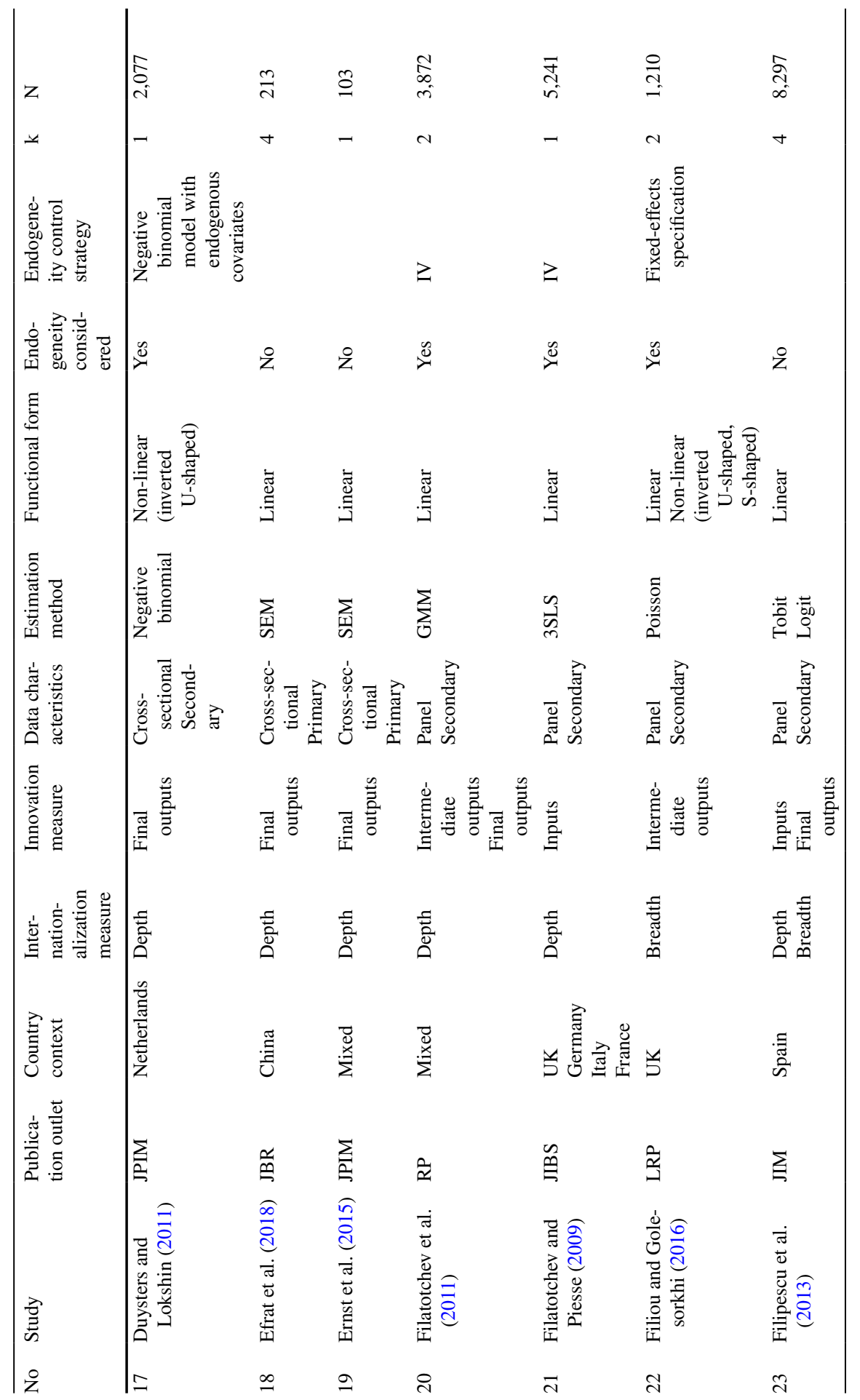




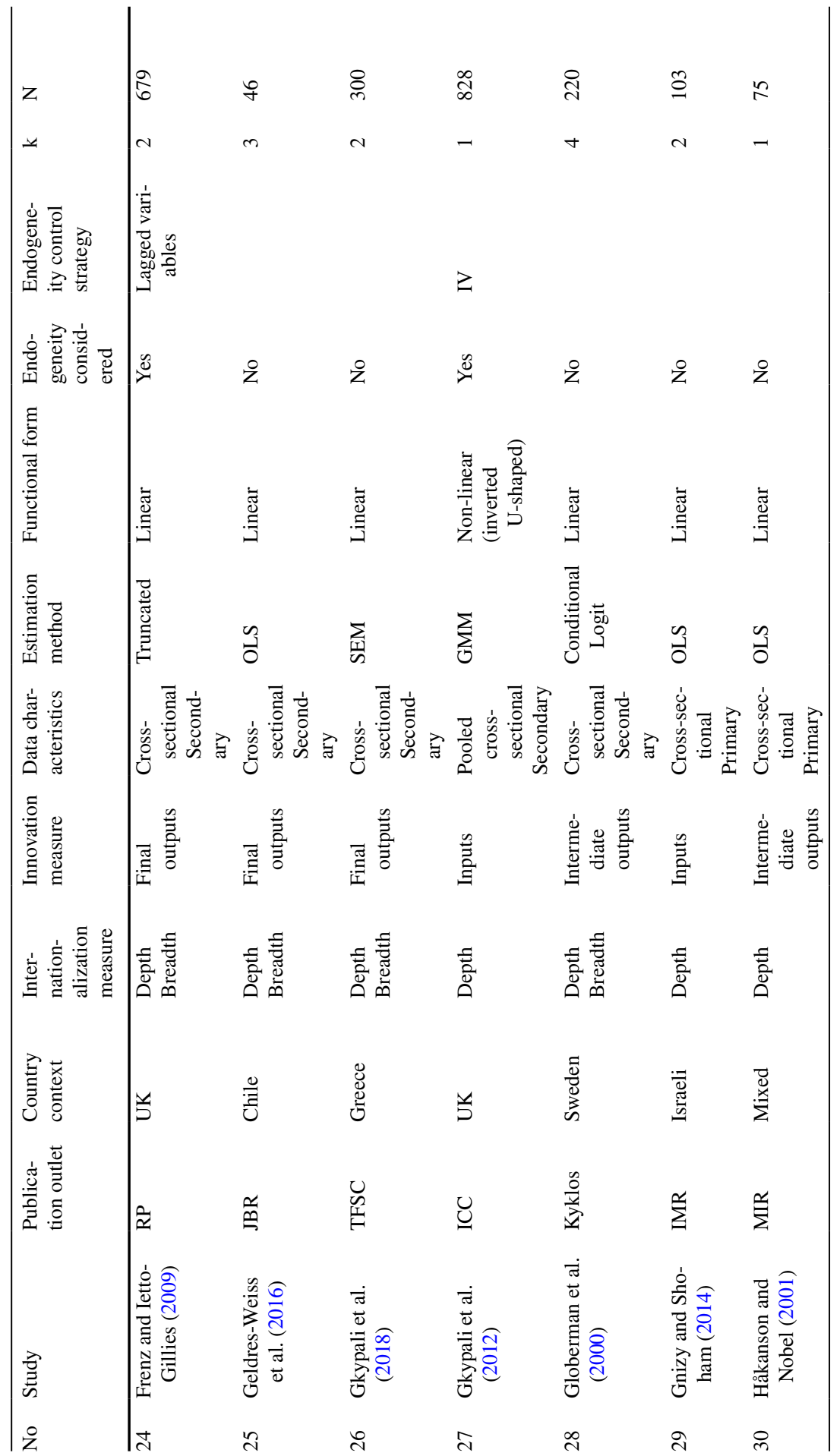




\begin{tabular}{|c|c|c|c|c|c|c|c|c|}
\hline z & $\stackrel{\wp}{\gtrless}$ & ๙ิ & $\begin{array}{l}\stackrel{\sigma}{O} \\
\text { i }\end{array}$ & $\begin{array}{l}\text { त̃ } \\
\text { i }\end{array}$ & ڤ్ণ & $\vec{q}$ & $\stackrel{2}{2}$ & $\stackrel{\text { I }}{2}$ \\
\hline$\triangle$ & - & - & $\mathrm{N}$ & N & $m$ & $N$ & - & - \\
\hline 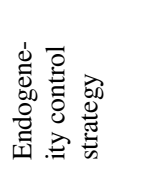 & $\geq$ & & 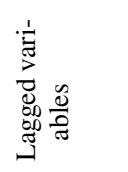 & 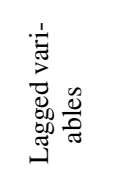 & 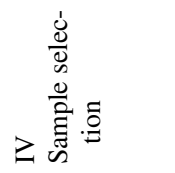 & 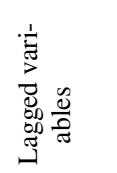 & & \\
\hline 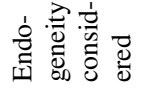 & $\stackrel{\otimes}{\infty}$ & ż & $\stackrel{\circlearrowright}{\infty}$ & $\stackrel{0}{0}$ & $\stackrel{0}{\infty}$ & $\stackrel{0}{\infty}$ & ż & ż \\
\hline 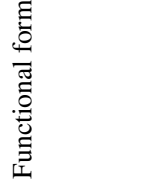 & 苛 & 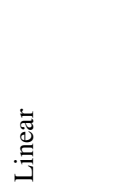 & 莺 & 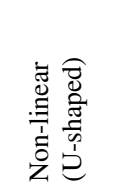 & 节 & 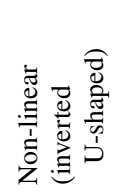 & 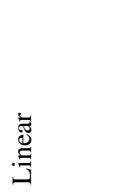 & 㺃 \\
\hline 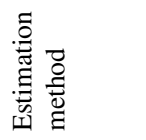 & 弪 & $\tilde{0}$ & 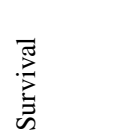 & $\tilde{0}$ & 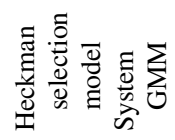 & 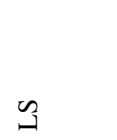 & $\tilde{3}$ & $\sum_{\text {至 }}$ \\
\hline 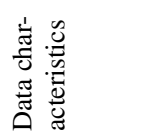 & 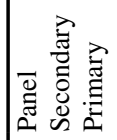 & 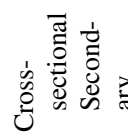 & 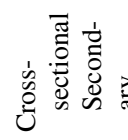 & 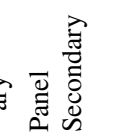 & 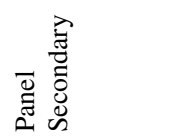 & 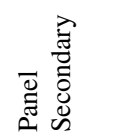 & 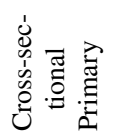 & 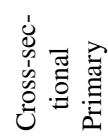 \\
\hline 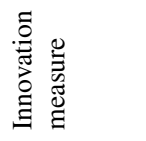 & 总 & 参 & 言 & 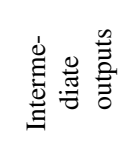 & 言 & 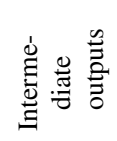 & 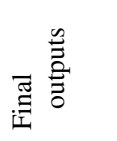 & 营 \\
\hline 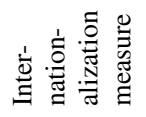 & 言 & $\begin{array}{l}\overline{\tilde{a}} \\
\stackrel{0}{0}\end{array}$ & $\begin{array}{l}\overline{0} \\
\stackrel{0}{0}\end{array}$ & 咅营 & $\begin{array}{l}\overline{\tilde{a}} \\
\text { Ф̆ }\end{array}$ & 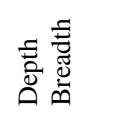 & $\begin{array}{l}\overline{\tilde{a}} \\
\text { Ф̆ }\end{array}$ & 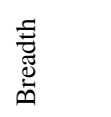 \\
\hline 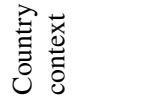 & 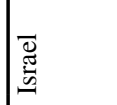 & & $\stackrel{\Omega}{\Omega}$ & 氞 & 耪 & $\stackrel{\vec{J}}{\stackrel{x}{*}}$ & 急 & $\stackrel{\vec{x}}{\stackrel{x}{*}}$ \\
\hline 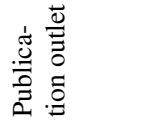 & $\underline{0}$ & $\sum$ & $\vec{ح}$ & $\stackrel{\mathscr{\mu}}{\mathscr{\theta}}$ & $\vec{a}$ & $\stackrel{\mathscr{\vartheta}}{\mathscr{\theta}}$ & 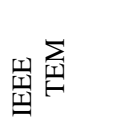 & $\cong$ \\
\hline 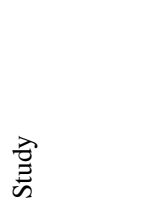 & 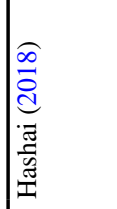 & 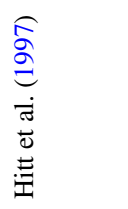 & 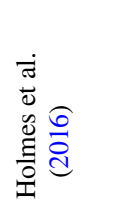 & 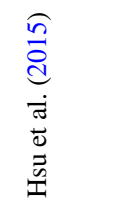 & 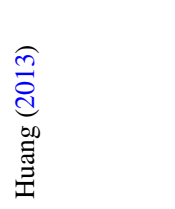 & 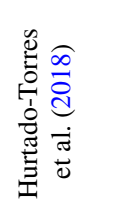 & 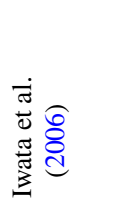 & 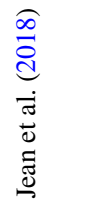 \\
\hline ż & $\mid \vec{m}$ & $\stackrel{N}{n}$ & $m$ & mे & $\stackrel{n}{n}$ & ల & $\hat{n}$ & $\stackrel{\infty}{m}$ \\
\hline
\end{tabular}




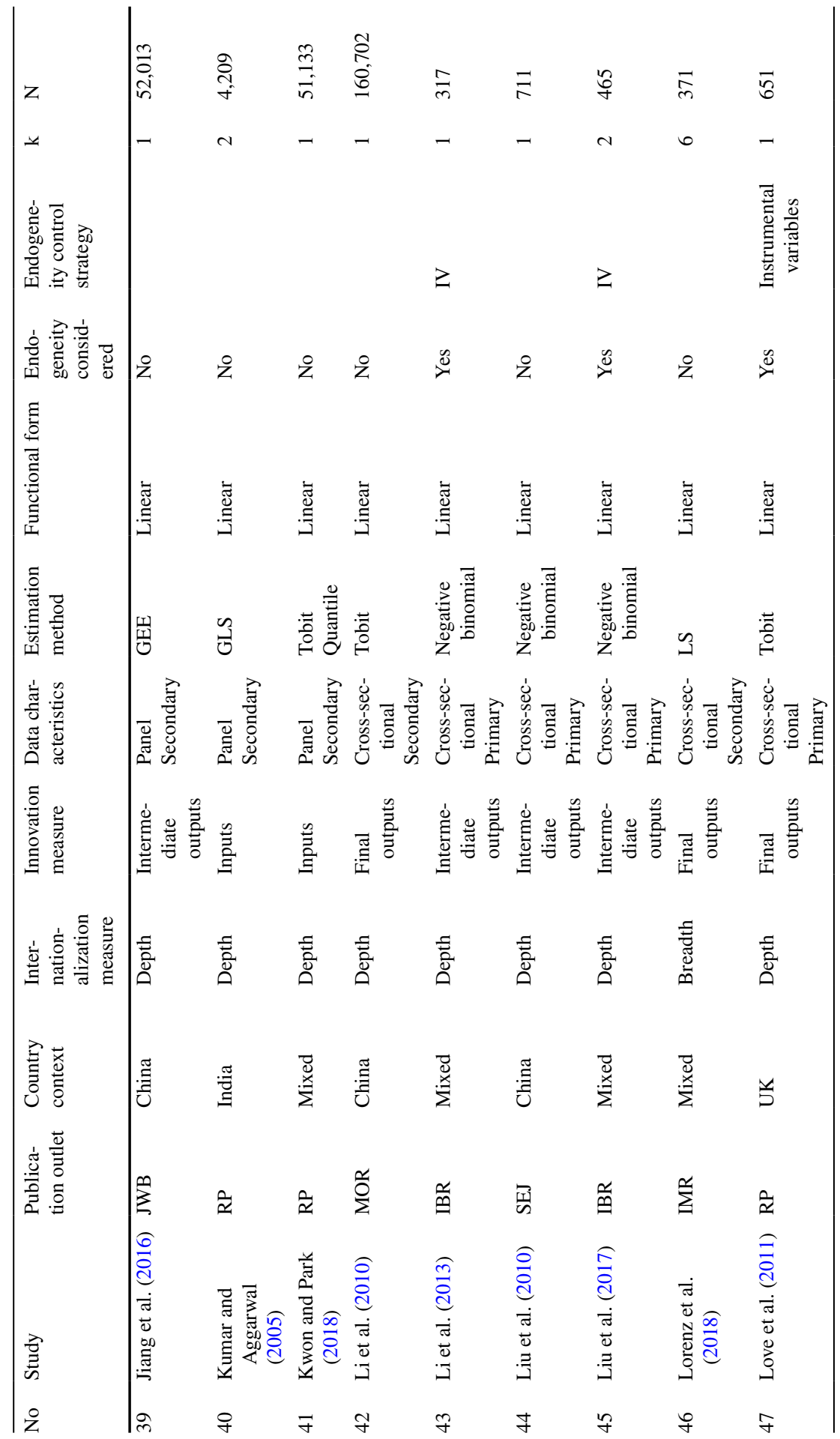




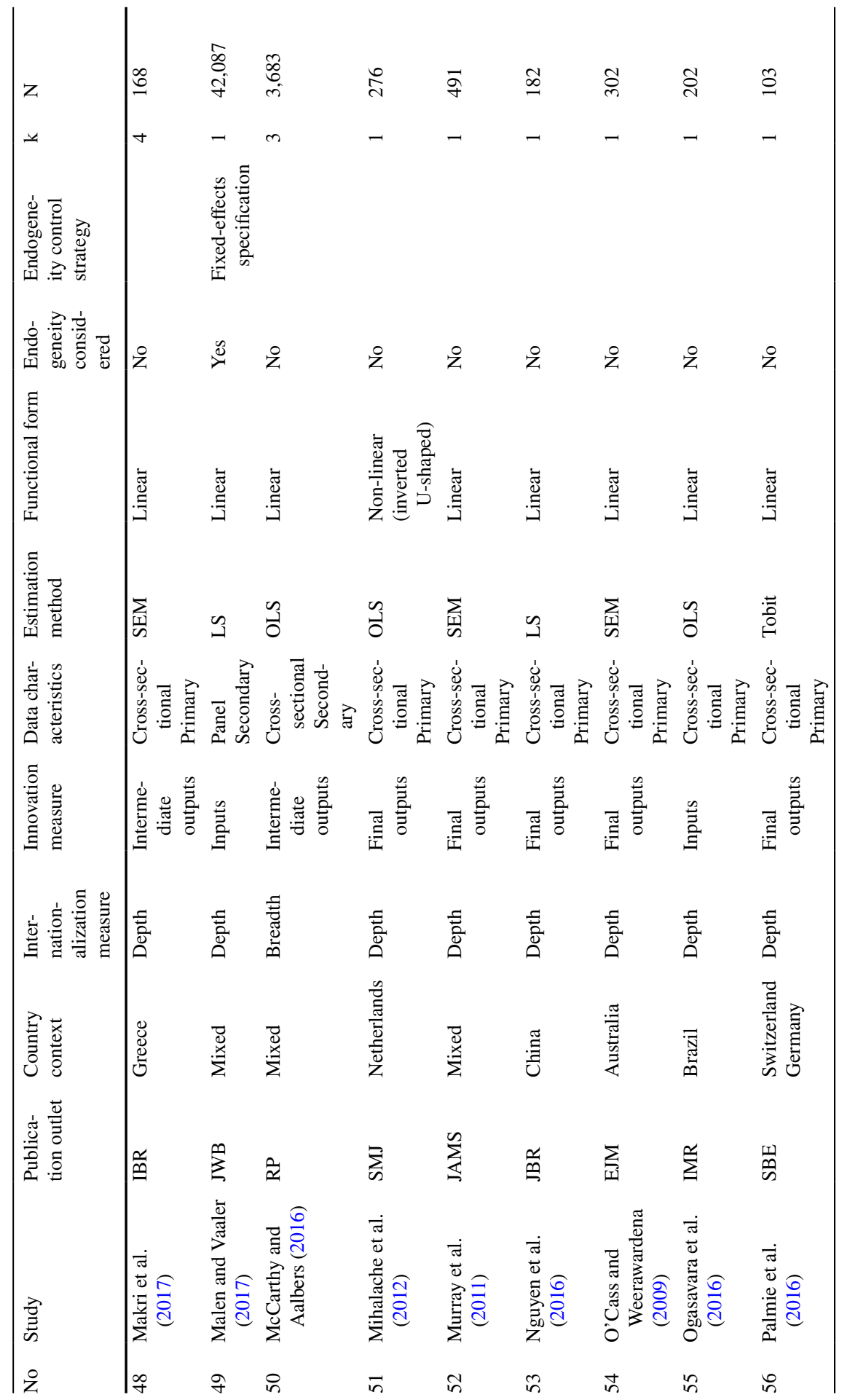




\begin{tabular}{|c|c|c|c|c|c|c|c|c|}
\hline z & : & 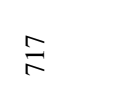 & ذ & 今ે & $\underset{+}{\Delta}$ & 京 & مे & $\stackrel{\circ}{\stackrel{\sim}{*}}$ \\
\hline$\leadsto$ & - & $m$ & - & $m$ & - & $\sim$ & $N$ & 0 \\
\hline 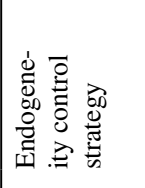 & & $\geq$ & & 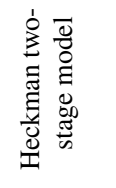 & 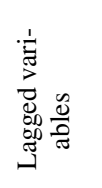 & 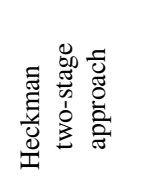 & 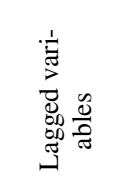 & \\
\hline 它穿紊 & ż & 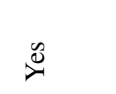 & ż & $\stackrel{\infty}{\check{\nu}}$ & $\stackrel{\Xi}{\check{\nu}}$ & $\stackrel{\infty}{ٍ}$ & $\stackrel{0}{\circlearrowright}$ & $\stackrel{\circ}{z}$ \\
\hline 善 & 营 & 䔍 & 营 & 莺 & $\stackrel{\mathscr{\varpi ̆}}{.}$ & 营 & 駕 & 营 \\
\hline 鞄 & 䓂 & 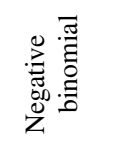 & $\tilde{3}$ & 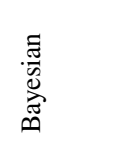 & $\stackrel{n}{0}$ & 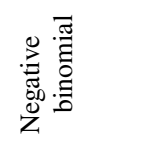 & 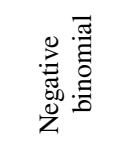 & 约 \\
\hline 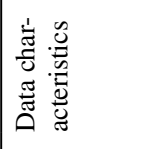 & 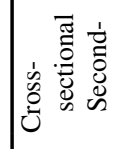 & 㕄 & 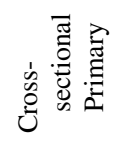 & 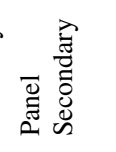 & 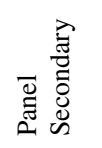 & 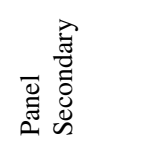 & 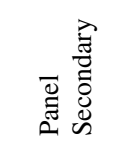 & 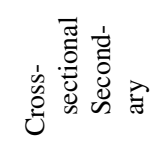 \\
\hline 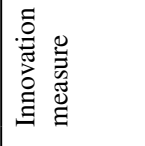 & 獣 & 总辤 & 总总善 & 总总 & 总总 & 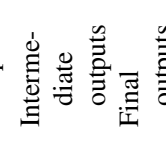 & 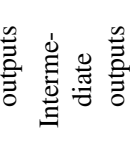 & 产产产 \\
\hline 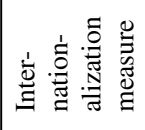 & 訔 & 竞 & 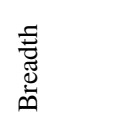 & 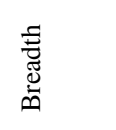 & $\begin{array}{l}\overline{\overline{0}} \\
\stackrel{0}{0}\end{array}$ & $\begin{array}{l}\overline{\overline{0}} \\
\stackrel{0}{0}\end{array}$ & 离 & 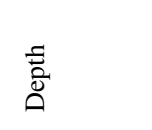 \\
\hline 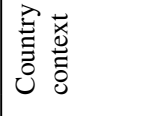 & 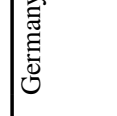 & 节 & 窓 & $\stackrel{\vec{u}}{\tilde{K}}$ & 节 & $\begin{array}{l}\text { : } \\
\text { की }\end{array}$ & $\begin{array}{l}\text { 寻 } \\
\text { की }\end{array}$ & 芠 \\
\hline 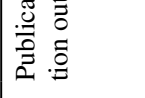 & $\sum_{n}^{\infty}$ & 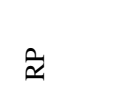 & $\sum^{n}$ & $\sum_{\Sigma}^{\infty}$ & $\stackrel{\widetilde{\mu}}{\mathscr{M}}$ & O & $\sum_{n=1}^{B}$ & $\stackrel{f}{\Sigma}$ \\
\hline 胥 & 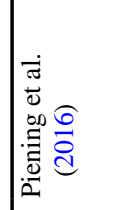 & 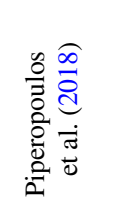 & 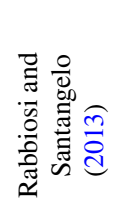 & 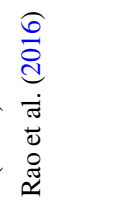 & 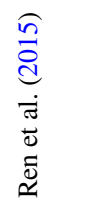 & 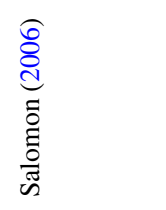 & 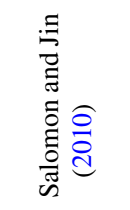 & 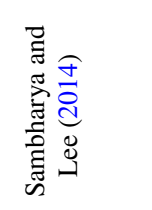 \\
\hline$\stackrel{2}{z}$ & in & $\infty$ & in & 8 & $\vec{\sigma}$ & $\widetilde{\delta}$ & 8 & t \\
\hline
\end{tabular}




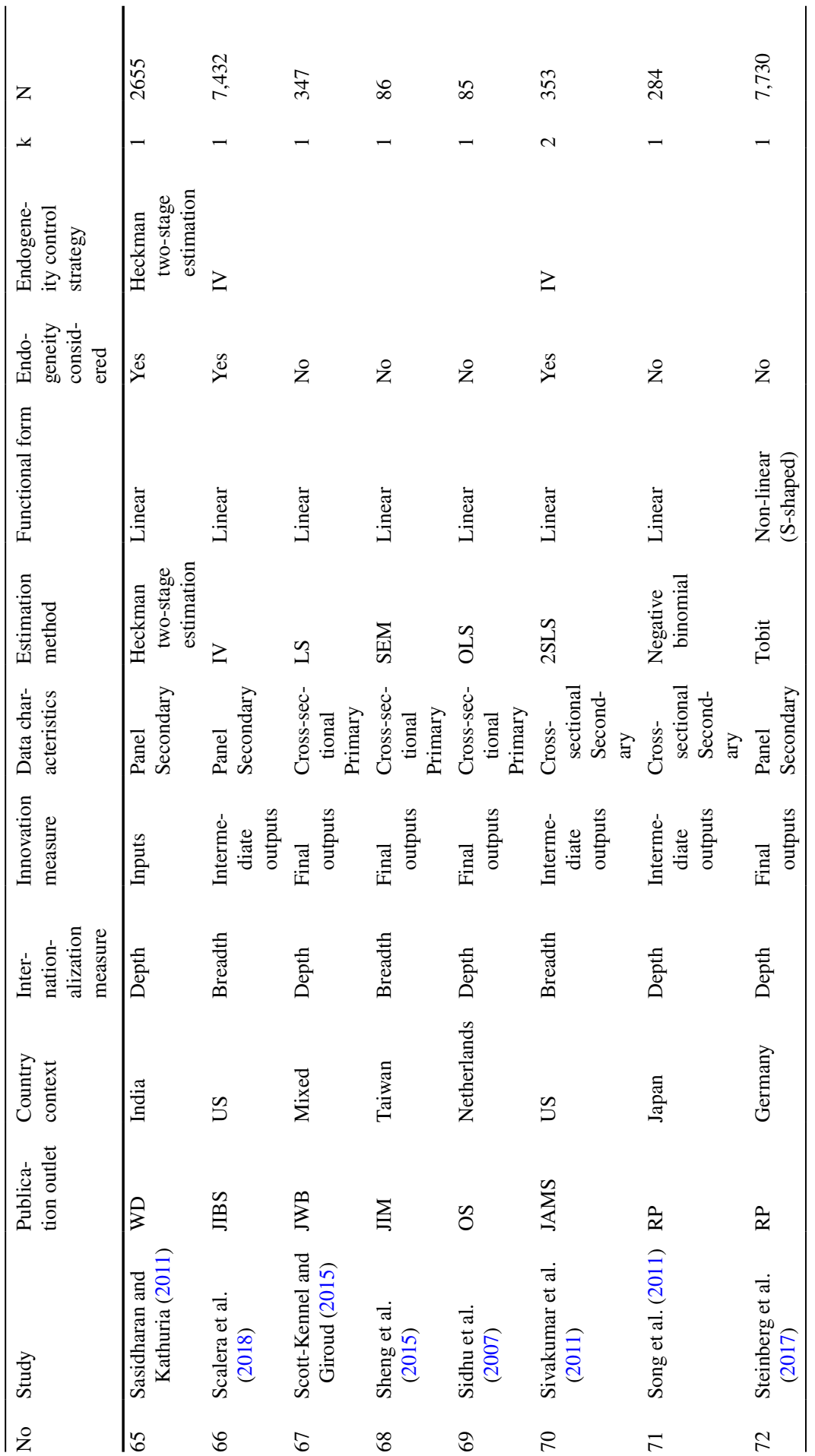




\begin{tabular}{|c|c|c|c|c|c|c|c|c|}
\hline Z & ฉ & of & $\begin{array}{l}\stackrel{\infty}{\star} \\
\underset{m}{m}\end{array}$ & $\frac{\hat{n}}{\hat{m}}$ & $\begin{array}{l}\text { co } \\
\stackrel{n}{n} \\
\stackrel{n}{2}\end{array}$ & $\stackrel{\vartheta}{\vec{n}}$ & 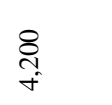 & $\stackrel{\hat{n}}{n}$ \\
\hline$\not$ & - & 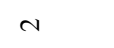 & $N$ & $\sim$ & - & $m$ & - & $\sim$ \\
\hline 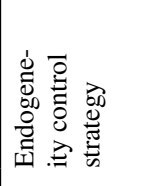 & & 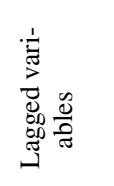 & 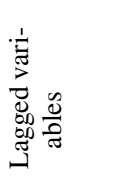 & 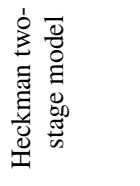 & $\geq$ & & & 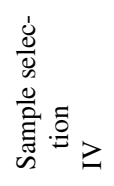 \\
\hline 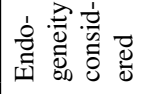 & $\ddot{z}$ & 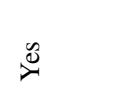 & $\stackrel{\infty}{\infty}$ & $\stackrel{\infty}{\circlearrowright}$ & 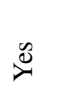 & ż & $\stackrel{\circ}{z}$ & $\stackrel{0}{\circlearrowright}$ \\
\hline 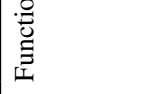 & 苛 & 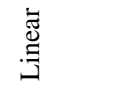 & .્ّ & 駕 & 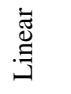 & 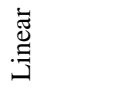 & 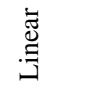 & 莺 \\
\hline 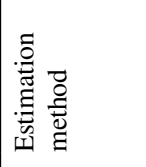 & $\Omega$ & 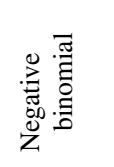 & $\tilde{3}$ & $\tilde{0}$ & $\sum_{U}^{\infty}$ & 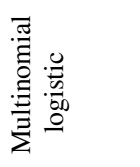 & 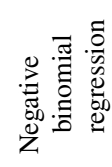 & 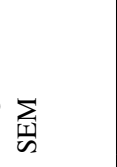 \\
\hline 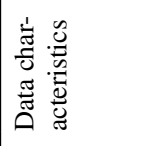 & 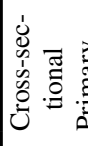 & 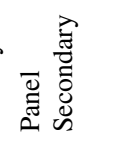 & 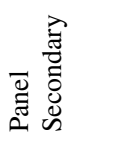 & 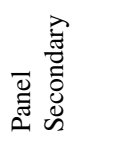 & 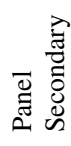 & 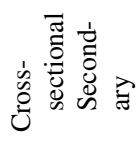 & 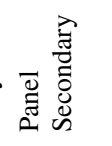 & 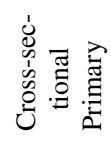 \\
\hline 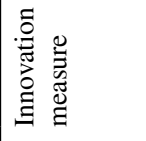 & 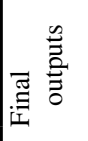 & 总 & 总总总 & 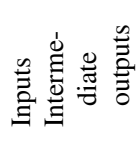 & 气 & 宓兽 & 氞 & 善莹言 \\
\hline 㐫咅芯 & 言 & 竞 & 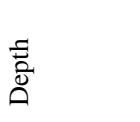 & 竞 & $\begin{array}{l}\text { ज्ञ̆ } \\
\text { ดे }\end{array}$ & 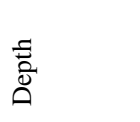 & 营 & $\begin{array}{l}\text { 苂 } \\
\text { ص̆ }\end{array}$ \\
\hline 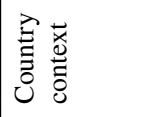 & 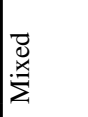 & : & 该 & 苞 & 莺 & $\begin{array}{l}\overline{\overparen{J}} \\
\stackrel{0}{0} \\
\stackrel{0}{0}\end{array}$ & $\begin{array}{l}\text { 品 } \\
\text { के }\end{array}$ & 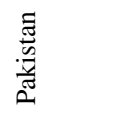 \\
\hline 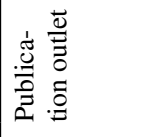 & 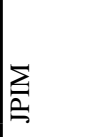 & $\sum$ & 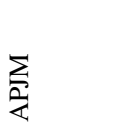 & $\cong$ & $\underset{0}{\sum_{0}}$ & 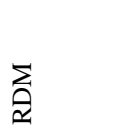 & $\tilde{\vartheta}$ & 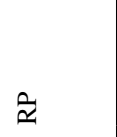 \\
\hline $\begin{array}{l}\vec{z} \\
\stackrel{\vec{D}}{n}\end{array}$ & 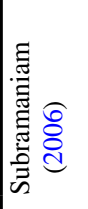 & 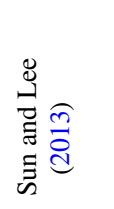 & 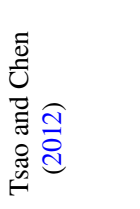 & 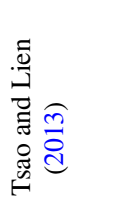 & 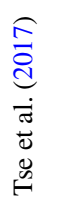 & 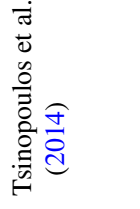 & 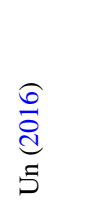 & 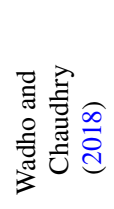 \\
\hline 8 & $\cong$ & $\underset{\sim}{\Delta}$ & 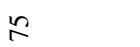 & $\stackrel{\imath}{\circ}$ & 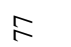 & $\stackrel{\infty}{\sim}$ & $\stackrel{\imath}{\imath}$ & $\infty$ \\
\hline
\end{tabular}




\begin{tabular}{|c|c|c|c|c|c|c|c|c|}
\hline z & $\vec{\circ}$ & $\begin{array}{l}\text { 寺 } \\
\text { i } \\
\text { I }\end{array}$ & ః्ల & $\begin{array}{l}n \\
\tilde{n} \\
=\end{array}$ & $\stackrel{\infty}{=}$ & $\frac{\bar{a}}{2}$ & $\stackrel{\Omega}{\beth}$ & $\begin{array}{l}\hat{\delta} \\
\dot{f}\end{array}$ \\
\hline$\triangle$ & - & $\nabla$ & - & $\nabla$ & $\sim$ & $\sim$ & - & - \\
\hline 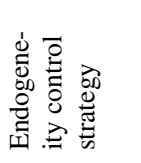 & & 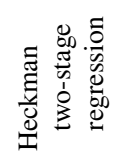 & & 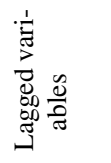 & & & & 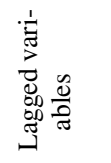 \\
\hline 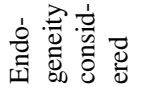 & z̊ & 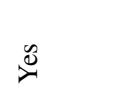 & $\stackrel{\circ}{z}$ & $\stackrel{\nabla}{\infty}$ & $\stackrel{\circ}{z}$ & ż & $\stackrel{\circ}{z}$ & 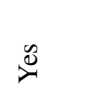 \\
\hline 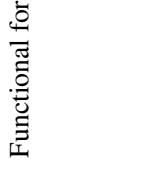 & 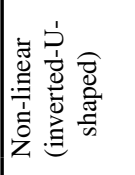 & 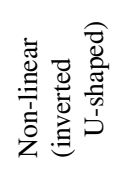 & 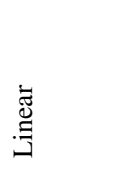 & 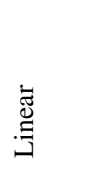 & 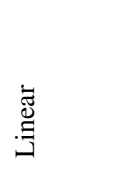 & 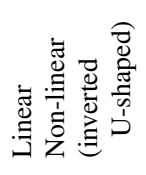 & 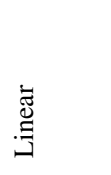 & 总 \\
\hline 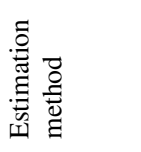 & 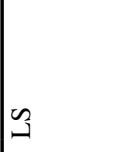 & $\tilde{3}$ & $\tilde{3}$ & 岀 & $\sum_{\text {岳 }}$ & 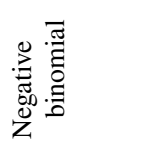 & 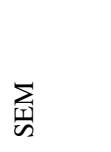 & 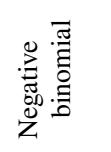 \\
\hline 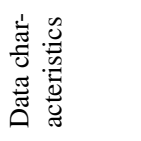 & 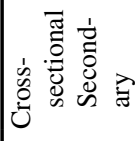 & 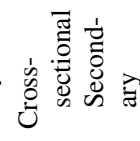 & 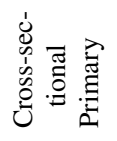 & 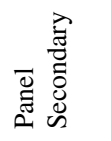 & 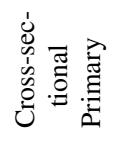 & 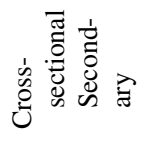 & 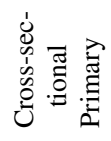 & 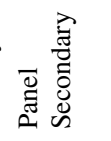 \\
\hline 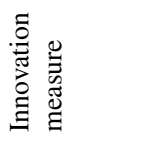 & 丞 & 䄈 & 急 & 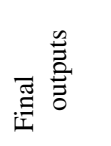 & 预 & 芳 & 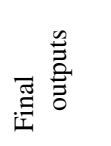 & 莺 \\
\hline 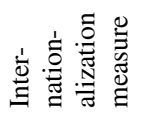 & 言 & $\begin{array}{l}\text { 苂 } \\
\text { ص̆ }\end{array}$ & 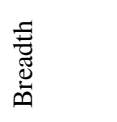 & 营 & $\begin{array}{l}\bar{\Xi} \\
\text { อ̃ }\end{array}$ & 节 & 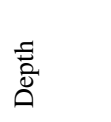 & 营 \\
\hline 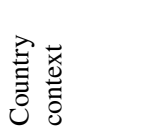 & $\Omega$ & 节 & $\stackrel{\vec{d}}{\stackrel{\mathscr{x}}{\Sigma}}$ & 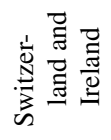 & $\tilde{s}$ & 苞 & 尝 & 急 \\
\hline 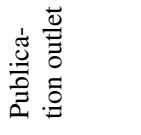 & $\sum$ & $\sum$ & 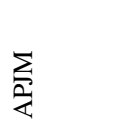 & $\stackrel{\vec{q}}{ }$ & $\sum_{\substack{n \\
\triangleq}}$ & $\stackrel{\Xi}{\Sigma}$ & $\stackrel{\mathscr{a}}{\mathscr{a}}$ & 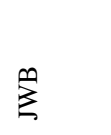 \\
\hline $\begin{array}{l}\text { 离 } \\
\text { 离 }\end{array}$ & 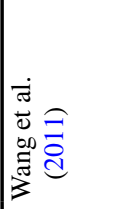 & 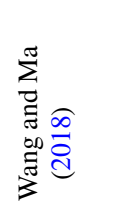 & 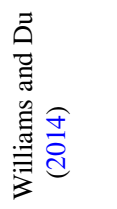 & 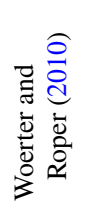 & 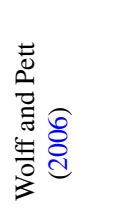 & $\begin{array}{c}\text { a } \\
\stackrel{d}{d} \\
\vdots \\
3\end{array}$ & 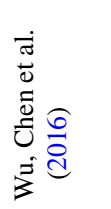 & 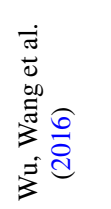 \\
\hline z̊ & $\vec{\infty}$ & $\widetilde{\infty}$ & $\infty$ & $\Phi$ & $\infty$ & $\infty$ & $\hat{\infty}$ & $\infty$ \\
\hline
\end{tabular}




\begin{tabular}{|c|c|c|c|c|c|c|c|c|c|}
\hline$z$ & fे & 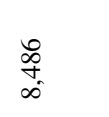 & 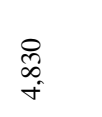 & $\begin{array}{l}\text { : } \\
\text { م. } \\
\circ\end{array}$ & $\begin{array}{l}\stackrel{m}{\hat{b}} \\
\frac{\vec{q}}{q}\end{array}$ & ફે & $\begin{array}{l}\text { d } \\
m \\
\infty \\
\infty \\
\infty\end{array}$ & $\overrightarrow{\widetilde{m}}$ & 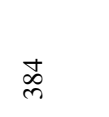 \\
\hline$\leadsto$ & - & $\nabla$ & - & - & - & - & - & $\stackrel{\sim}{\sim}$ & 0 \\
\hline 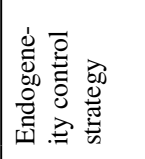 & & 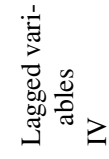 & 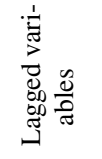 & 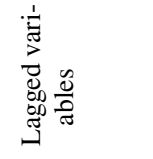 & 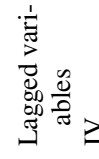 & & 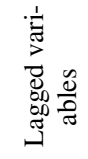 & & \\
\hline 它害离 & 文 & 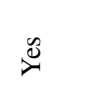 & $\stackrel{0}{\check{\nu}}$ & $\stackrel{\infty}{\infty}$ & $\stackrel{0}{\check{\nu}}$ & ż & $\stackrel{\widetilde{N}}{\mathscr{N}}$ & ż & z \\
\hline 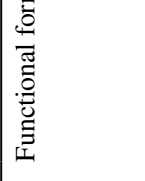 & 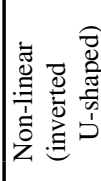 & 䔍 & 駕 & 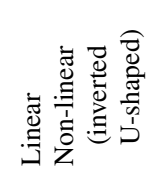 & ๑ँّ & 营 & 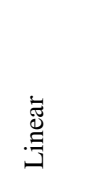 & 駕 & 氠 \\
\hline 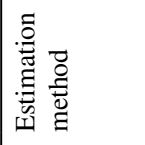 & 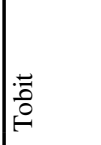 & 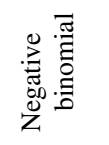 & 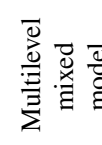 & : & 岂 & 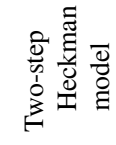 & $\Omega$ & & 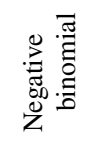 \\
\hline 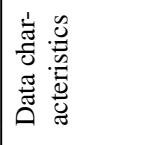 & 焉 & 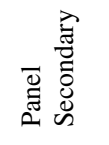 & 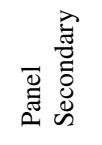 & 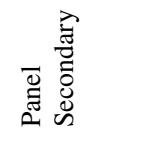 & 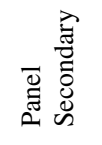 & 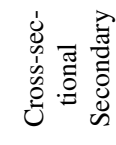 & 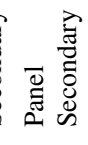 & 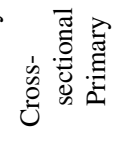 & 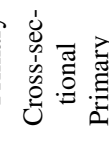 \\
\hline 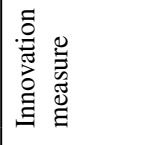 & 獣 & 总总 & 部言 & 言 & 彗言 & 旁 & 茎言 & 舜言 & 畄 \\
\hline 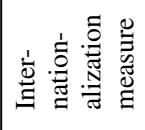 & 言 & 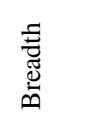 & $\begin{array}{l}\overline{\bar{a}} \\
\stackrel{0}{0}\end{array}$ & 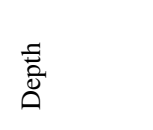 & 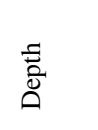 & 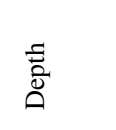 & 䓂 & 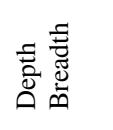 & 吾莺 \\
\hline 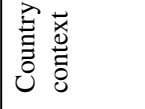 & שี & 节 & 节 & 节 & 栉 & 蔦 & 节 & 5 & $\tilde{s}$ \\
\hline 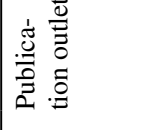 & $\stackrel{\sim}{\underline{\theta}}$ & $\stackrel{\widetilde{\mu}}{\mathscr{\theta}}$ & 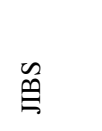 & $\underset{g}{\Xi}$ & 气ै & 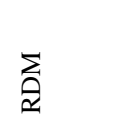 & 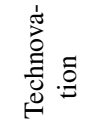 & $\sum_{<}^{2}$ & $\sum_{i=1}^{\cong}$ \\
\hline 莺 & 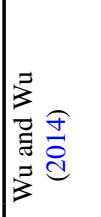 & 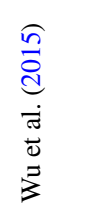 & 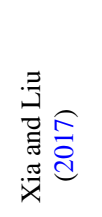 & 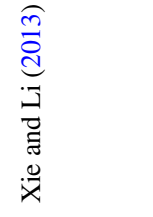 & 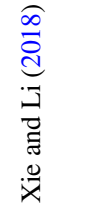 & 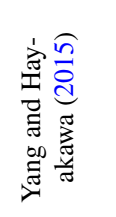 & 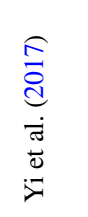 & 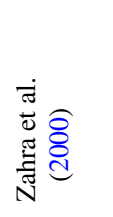 & 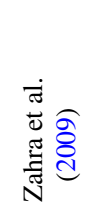 \\
\hline ż & |ळ & \& & $\bar{a}$ & $\alpha$ & $\kappa$ & t & $\curvearrowleft$ & ஃ & $\hat{a}$ \\
\hline
\end{tabular}




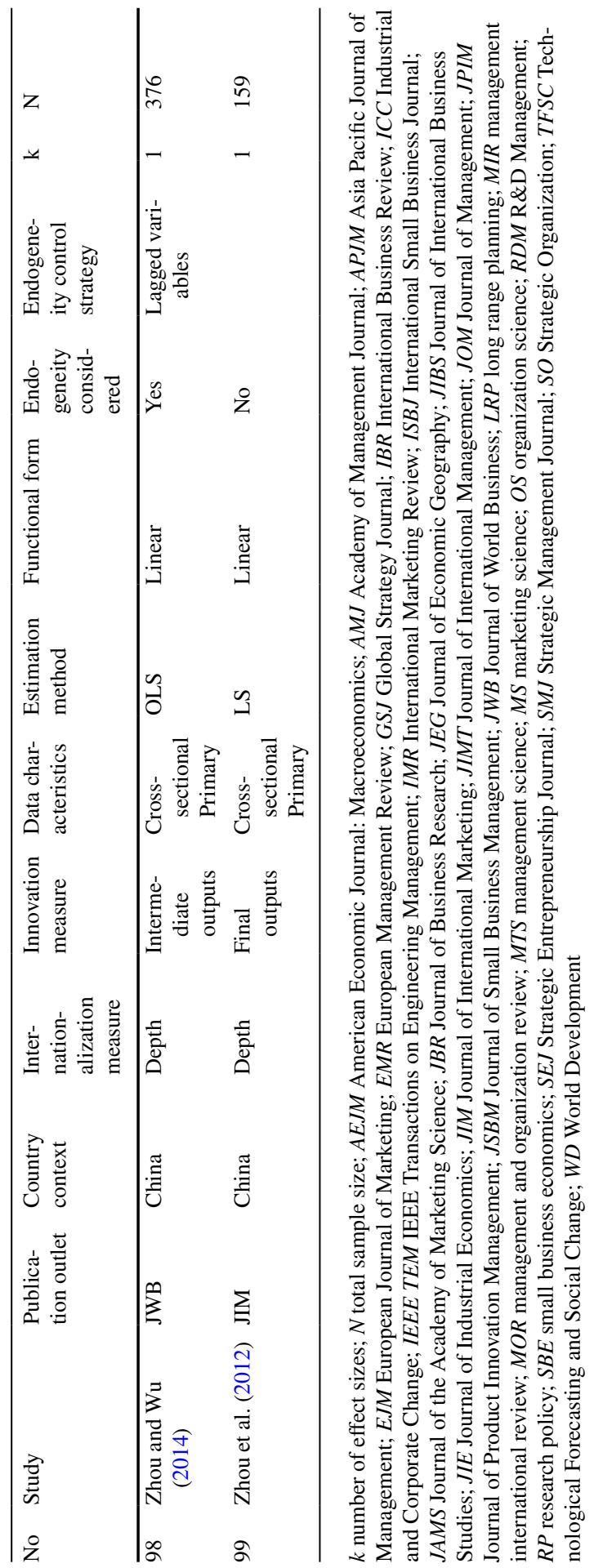




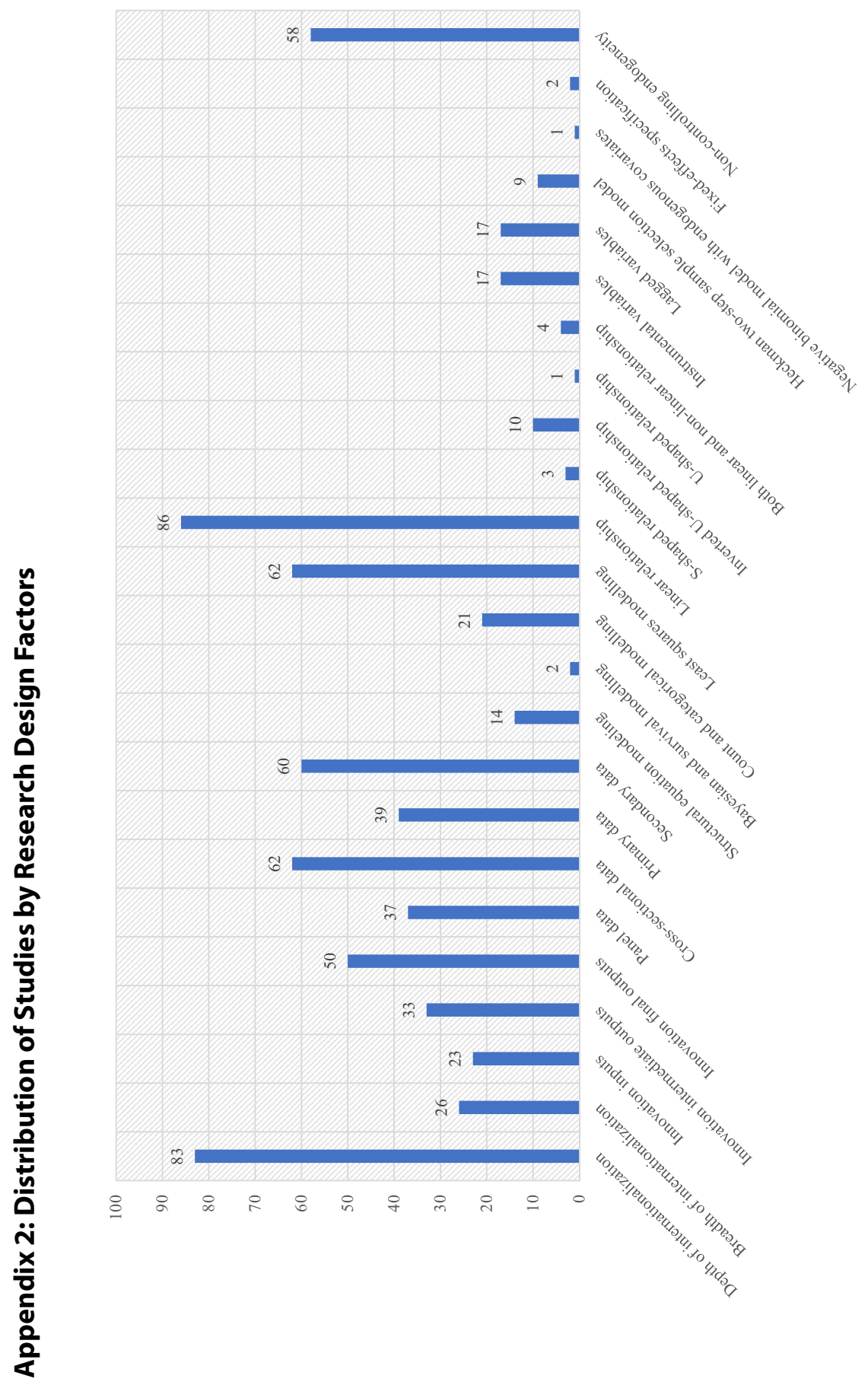


Acknowledgement The authors thank Angela Wang for her meticulous copyediting, though we take full responsibility for any remaining errors.

Funding This research was funded by National Nature Science Foundation of China, Grant number [71832012].

Open Access This article is licensed under a Creative Commons Attribution 4.0 International License, which permits use, sharing, adaptation, distribution and reproduction in any medium or format, as long as you give appropriate credit to the original author(s) and the source, provide a link to the Creative Commons licence, and indicate if changes were made. The images or other third party material in this article are included in the article's Creative Commons licence, unless indicated otherwise in a credit line to the material. If material is not included in the article's Creative Commons licence and your intended use is not permitted by statutory regulation or exceeds the permitted use, you will need to obtain permission directly from the copyright holder. To view a copy of this licence, visit http://creativecommons.org/licen ses/by/4.0/.

\section{References}

Aguinis, H., Cascio, W. F., \& Ramani, R. S. (2017). Science's reproducibility and replicability crisis: International business is not immune. Journal of International Business Studies, 48(6), 653-663.

Almeida, P., \& Phene, A. (2004). Subsidiaries and knowledge creation: The influence of the MNC and host country on innovation. Strategic Management Journal, 25(8-9), 847-864.

Amendolagine, V., Giuliani, E., Martinelli, A., \& Rabellotti, R. (2018). Chinese and Indian MNEs' shopping spree in advanced countries. How good is it for their innovative output? Journal of Economic Geography, 18(5), 1149-1176.

Arundel, A., \& Kabla, I. (1998). What percentage of innovation are patented? Emprical estimates for European firms. Research Policy, 27(2), 127-141.

Azar, G., \& Drogendijk, R. (2014). Psychic distance, innovation, and firm performance. Management International Review, 54(5), 581-613.

Bascle, G. (2008). Controlling for endogeneity with instrumental variables in strategic management research. Strategic Organization, 6(3), 285-327.

Bausch, A., \& Krist, M. (2007). The effect of context-related moderators on the internationalizationperformance relationship: Evidence from meta-analysis. Management International Review, 47(3), 319-347.

Belderbos, R. (2001). Overseas innovations by Japanese firms: An analysis of patent and subsidiary data. Research Policy, 30(2), 313-332.

Belderbos, R. (2003). Entry mode, organizational learning, and R\&D in foreign affiliates: Evidence from Japanese firms. Strategic Management Journal, 24(3), 235-259.

Belderbos, R., Leten, B., \& Suzuki, S. (2013). How global is R\&D? Firm-level determinants of homecountry bias in R\&D. Journal of International Business Studies, 44(8), 765-786.

Bergh, D. D., Aguinis, H., Heavey, C., Ketchen, D. J., Boyd, B. K., Su, P., Lau, C. L. L., \& Joo, H. (2016). Using meta-analytic structural equation modeling to advance strategic management research: Guidelines and an empirical illustration via the strategic leadership-performance relationship. Strategic Management Journal, 37(3), 477-497.

Beugelsdijk, S., Hennart, J.-F., Slangen, A., \& Smeets, R. (2010). Why and how FDI stocks are a biased measure of MNE affiliate activity. Journal of International Business Studies, 41(9), 1444-1459.

Beugelsdijk, S., Kostova, T., Kunst, V. E., Spadafora, E., \& van Essen, M. (2018). Cultural distance and firm internationalization: A meta-analytical review and theoretical implications. Journal of Management, 44(1), 89-130.

Birkinshaw, J., \& Fey, C. F. (2003). Organization of research and development in large multinational firms. Management International Review, 43(3), 27-46.

Bono, J. E., \& McNamara, G. (2011). Publishing in AMJ_part 2: Research design. Academy of Management Journal, 54(4), 657-660. 
Boso, N., Cadogan, J. W., \& Story, V. M. (2013). Entrepreneurial orientation and market orientation as drivers of product innovation success: A study of exporters from a developing economy. International Small Business Journal, 31(1), 57-81.

Bowen, F. E., Rostami, M., \& Steel, P. (2010). Timing is everything: A meta-analysis of the relationships between organizational performance and innovation. Journal of Business Research, 63(11), 1179-1185.

Boyd, B. K., \& Solarino, A. M. (2016). Ownership of corporations: A review, synthesis and research agenda. Journal of Management, 42(5), 1282-1314.

Brouwer, E., \& Kleinknecht, A. (1999). Innovative output, and a firm's propensity to patent: An exploration of CIS micro data. Research Policy, 28(6), 615-624.

Camisón-Zornoza, C., Lapiedra-Alcamí, R., Segarra-Ciprés, M., \& Boronat-Navarro, M. (2004). A metaanalysis of innovation and organizational size. Organization Studies, 25(3), 331-361.

Castellani, D., Montresor, S., Schubert, T., \& Vezzani, A. (2017). Multinationality, R\&D and productivity: Evidence from the top R\&D investors worldwide. International Business Review, 26(3), 405-416.

Chen, C. J., \& Hsiao, Y. C. (2013). The endogenous role of location choice in product innovations. Journal of World Business, 48(3), 360-372.

Chen, C.-J., Huang, Y.-F., \& Lin, B.-W. (2012). How firms innovate through R\&D internationalization? An S-Curve Hypothesis. Research Policy, 41(9), 1544-1554.

Cheng, C., \& Yang, M. (2017). Enhancing performance of cross-border mergers and acquisitions in developed markets: The role of business ties and technological innovation capability. Journal of Business Research, 81, 107-117.

Chetty, S., Johanson, M., \& Martín Martín, O. (2014). Speed of internationalization: Conceptualization, measurement and validation. Journal of World Business, 49(4), 633-650.

Chittoor, R., Aulakh, P. S., \& Ray, S. (2015). Accumulative and assimilative Learning, institutional infrastructure, and innovation orientation of developing economy firms. Global Strategy Journal, 5(2), $133-153$.

Cohen, J. (1988). Statistical power analysis for the behavioral sciences. Lawrence Erlbaum Associates Publishers.

Contractor, F. J. (2007). Is international business good for companies? The evolutionary or multi-stage theory of internationalization vs. the transaction cost perspective. Management International Review, 47(3), 453-475.

Coviello, N. E., \& Jones, M. V. (2004). Methodological issues in international entrepreneurship research. Journal of Business Venturing, 19(4), 485-508.

Cowton, C. J. (1998). The use of secondary data in business ethics research. Journal of Business Ethics, 17(4), 423-434.

Cuervo-Cazurra, A., Andersson, U., Brannen, M. Y., Nielsen, B. B., \& Reuber, R. A. (2016). From the Editors: Can I trust your findings? Ruling out alternative explanations in international business research. Journal of International Business Studies, 47(8), 881-897.

Damijan, J. P., \& Kostevc, Č. (2015). Learning from trade through innovation. Oxford Bulletin of Economics and Statistics, 77(3), 408-436.

de Brentani, U., Kleinschmidt, E. J., \& Salomo, S. (2010). Success in global new product development: Impact of strategy and the behavioral environment of the firm. Journal of Product Innovation Management, 27(2), 143-160.

Deligianni, I., Voudouris, I., \& Lioukas, S. (2014). The relationship between innovation and diversification in the case of new ventures: Unidirectional or bidirectional? IEEE Transactions on Engineering Management, 61(3), 462-475.

Denrell, J., Arvidsson, N., \& Zander, U. (2004). Managing knowledge in the dark: An empirical study of the reliability of capability evaluations. Management Science, 50(11), 1491-1503.

Dimos, C., \& Pugh, G. (2016). The effectiveness of R\&D subsidies: A meta-regression analysis of the evaluation literature. Research Policy, 45(4), 797-815.

Duysters, G., \& Lokshin, B. (2011). Determinants of alliance portfolio complexity and its effect on innovative performance of companies. Journal of Product Innovation Management, 28(4), 570-585.

Dziallas, M., \& Blind, K. (2019). Innovation indicators throughout the innovation process: An extensive literature analysis. Technovation, 80-81, 3-29.

Efrat, K., Hughes, P., Nemkova, E., Souchon, A. L., \& Sy-Changco, J. (2018). Leveraging of dynamic export capabilities for competitive advantage and performance consequences: Evidence from China. Journal of Business Research, 84, 114-124. 
Ernst, H., Kahle, H. N., Dubiel, A., Prabhu, J., \& Subramaniam, M. (2015). The antecedents and consequences of affordable value innovations for emerging markets. Journal of Product Innovation Management, 32(1), 65-79.

Filatotchev, I., Liu, X., Lu, J., \& Wright, M. (2011). Knowledge spillovers through human mobility across national borders: Evidence from Zhongguancun Science Park in China. Research Policy, 40(3), 453-462.

Filatotchev, I., \& Piesse, J. (2009). R\&D, internationalization and growth of newly listed firms: European evidence. Journal of International Business Studies, 40(8), 1260-1276.

Filiou, D., \& Golesorkhi, S. (2016). Influence of institutional differences on firm innovation from international alliances. Long Range Planning, 49(1), 129-144.

Filipescu, D. A., Prashantham, S., Rialp, A., \& Rialp, J. (2013). Technological innovation and exports: Unpacking their reciprocal causality. Journal of International Marketing, 21(1), 23-38.

Frenz, M., \& Ietto-Gillies, G. (2009). The impact on innovation performance of different sources of knowledge: Evidence from the UK Community Innovation Survey. Research Policy, 38(7), 1125-1135.

Geldres-Weiss, V. V., Uribe-Bórquez, C. T., Coudounaris, D. N., \& Monreal-Pérez, J. (2016). Innovation and experiential knowledge in firm exports: Applying the initial U-model. Journal of Business Research, 69(11), 5076-5081.

Geng, R. Q., Mansouri, A., \& Aktas, E. (2017). The relationship between green supply chain management and performance: A meta-analysis of empirical evidences in Asian emerging economies. International Journal of Production Economics, 183, 245-258.

Geyskens, I., Krishnan, R., Steenkamp, J.-B. E. M., \& Cunha, P. V. (2009). A review and evaluation of meta-analysis practices in management research. Journal of Management, 35(2), 393-419.

Gkypali, A., Arvanitis, S., \& Tsekouras, K. (2018). Absorptive capacity, exporting activities, innovation openness and innovation performance: A SEM approach towards a unifying framework. Technological Forecasting and Social Change, 132, 143-155.

Gkypali, A., Tsekouras, K., \& von Tunzelmann, N. (2012). Endogeneity between internationalization and knowledge creation of global R\&D leader firms: An econometric approach using Scoreboard data. Industrial and Corporate Change, 21(3), 731-762.

Globerman, S., Kokko, A., \& Sjoholm, F. (2000). International technology diffusion: Evidence from Swedish patent data. Kyklos, 53(1), 17-38.

Gnizy, I., \& Shoham, A. (2014). Uncovering the influence of the international marketing function in international firms. International Marketing Review, 31(1), 51-78.

Görg, H., \& Strobl, E. (2001). Multinational companies and productivity spillovers: A Meta-analysis. Economic Journal, 111(475), 723-739.

Grinstein, A. (2008). The effect of market orientation and its components on innovation consequences: A meta-analysis. Journal of the Academy of Marketing Science, 36(2), 166-173.

Hagedoorn, J., \& Cloodt, M. (2003). Measuring innovative performance: Is there an advantage in using multiple indicators? Research Policy, 32(8), 1365-1379.

Håkanson, L., \& Nobel, R. (2001). Organizational characteristics and reverse technology transfer. Management International Review, 41(4), 395-420.

Hamilton, B. H., \& Nickerson, J. A. (2003). Correcting for endogeneity in strategic management research. Strategic Organization, 1(1), 51-78.

Harris, H. (2001). Content analysis of secondary data: A study of courage in managerial decision making. Journal of Business Ethics, 34(3), 191-208.

Hashai, N. (2018). Focusing the high-technology firm: How outsourcing affects technological knowledge exploration. Journal of Management, 44(5), 1736-1765.

Hennart, J.-F. (2011). A theoretical assessment of the empirical literature on the impact of multinationality on performance. Global Strategy Journal, 1(1-2), 135-151.

Hitt, M. A., Hoskisson, R. E., \& Kim, H. (1997). International diversification: Effects on innovation and firm performance in product-diversified firms. Academy of Management Journal, 40(4), 767-798.

Hitt, M. A., Tihanyi, L., Miller, T., \& Connelly, B. (2006). International diversification: Antecedents, outcomes, and moderators. Journal of Management, 32(6), 831-867.

Holmes, R. M., Li, H. Y., Hitt, M. A., DeGhetto, K., \& Sutton, T. (2016). The Effects of Location and MNC Attributes on MNCs' Establishment of Foreign R\&D Centers: Evidence from China. Long Range Planning, 49(5), 594-613.

Hotho, J. J., Lyles, M. A., \& Easterby-Smith, M. (2015). The mutual impact of global strategy and organizational learning: Current themes and future directions. Global Strategy Journal, 5(2), 85-112. 
Hsu, C. W., Lien, Y. C., \& Chen, H. M. (2015). R\&D internationalization and innovation performance. International Business Review, 24(2), 187-195.

Huang, S. C. (2013). Capital outflow and R\&D investment in the parent firm. Research Policy, 42(1), $245-260$.

Hurtado-Torres, N. E., Aragon-Correa, J. A., \& Ortiz-de-Mandojana, N. (2018). How does R\&D internationalization in multinational firms affect their innovative performance? The moderating role of international collaboration in the energy industry. International Business Review, 27(3), 514-527.

Iwata, S., Kurokawa, S., \& Fujisue, K. (2006). An analysis of global R\&D activities of Japanese MNCs in the US from the knowledge-based view. IEEE Transactions on Engineering Management, 53(3), 361-379.

Jean, R. J., Sinkovics, R. R., \& Zagelmeyer, S. (2018). Antecedents and innovation performance implications of MNC political ties in the Chinese automotive supply chain. Management International Review, 58(6), 995-1026.

Jiang, M. S., Branzei, O., \& Xia, J. (2016). DIY: How internationalization shifts the locus of indigenous innovation for Chinese firms. Journal of World Business, 51(5), 662-674.

Kafouros, M. I., \& Buckley, P. J. (2008). Under what conditions do firms benefit from the research efforts of other organizations? Research Policy, 37(2), 225-239.

Kafouros, M. I., Buckley, P. J., \& Clegg, J. (2012). The effects of global knowledge reservoirs on the productivity of multinational enterprises: The role of international depth and breadth. Research Policy, 41(5), 848-861.

Kafouros, M. I., Buckley, P. J., Sharp, J. A., \& Wang, C. Q. (2008). The role of internationalization in explaining innovation performance. Technovation, 28(1-2), 63-74.

Kirca, A. H., Hult, G. T. M., Roth, K., Cavusgil, S. T., Perryy, M. Z., Akdeniz, M. B., Deligonul, S. Z., Mena, J. A., Pollitte, W. A., Hoppner, J. J., Miller, J. C., \& White, R. C. (2011). Firm-specific assets, multinationality and financial performance: A meta-analytic review and theoretical integration. Academy of Management Journal, 54(1), 47-72.

Kirca, A. H., Roth, K., Hult, G. T. M., \& Cavusgil, S. T. (2012). The role of context in the multinationality-performance relationship: A meta-analytic review. Global Strategy Journal, 2(2), 108-121.

Kostova, T., \& Hult, G. T. M. (2016). Meyer and Peng's 2005 article as a foundation for an expanded and refined international business research agenda: Context, organizations, and theories. Journal of International Business Studies, 47(1), 23-32.

Kumar, N., \& Aggarwal, A. (2005). Liberalization, outward orientation and in-house R\&D activity of multinational and local firms: A quantitative exploration for Indian manufacturing. Research Policy, 34(4), 441-460.

Kwon, H. U., \& Park, J. (2018). R\&D, foreign ownership, and corporate groups: Evidence from Japanese firms. Research Policy, 47(2), 428-439.

Lachenmaier, S., \& Wossmann, L. (2006). Does innovation cause exports? Evidence from exogenous innovation impulses and obstacles using German micro data. Oxford Economic Papers, 58(2), 317-350.

Li, J., Chen, D., \& Shapiro, D. M. (2010). Product innovations in emerging economies: The role of foreign knowledge access channels and internal efforts in Chinese firms. Management and Organization Review, 6(2), 243-266.

Li, L. (2007). Multinationality and performance: A synthetic review and research agenda. International Journal of Management Reviews, 9(2), 117-139.

Li, X. Y., Wang, J., \& Liu, X. M. (2013). Can locally-recruited R\&D personnel significantly contribute to multinational subsidiary innovation in an emerging economy? International Business Review, 22(4), 639-651.

Lipsey, M. W., \& Wilson, D. B. (2001). Practical Meta-Analysis. Sage Publications, Inc.

Liu, Q., \& Qiu, L. D. (2016). Intermediate input imports and innovations: Evidence from Chinese firms' patent filings. Journal of International Economics, 103, 166-183.

Liu, X. H., Lu, J. Y., Filatotchev, I., Buck, T., \& Wright, M. (2010). Returnee entrepreneurs, knowledge spillovers and innovation in high-tech firms in emerging economies. Journal of International Business Studies, 41(7), 1183-1197.

Liu, X. M., Vahtera, P., Wang, C. G., Wang, J., \& Wei, Y. Q. (2017). The delicate balance: Managing technology adoption and creation in multinational affiliates in an emerging economy. International Business Review, 26(3), 515-526.

Lorenz, M. P., Clampit, J., \& Ramsey, J. R. (2018). Distance is a Janus: An exploratory study of offshored innovation. International Marketing Review, 35(3), 518-546. 
Love, J. H., Roper, S., \& Bryson, J. R. (2011). Openness, knowledge, innovation and growth in UK business services. Research Policy, 40(10), 1438-1452.

Ma, L., Chen, A., \& Zhang, Z.-X. (2016). Task success based on contingency fit of managerial culture and embeddedness. Journal of International Business Studies, 47(2), 191-209.

Makri, K., Theodosiou, M., \& Katsike, E. (2017). An empirical investigation of the antecedents and performance outcomes of export innovativeness. International Business Review, 26(4), 628-639.

Malen, J., \& Vaaler, P. M. (2017). Organizational slack, national institutions and innovation effort around the world. Journal of World Business, 52(6), 782-797.

Marano, V., Arregle, J.-L., Hitt, M. A., Spadafora, E., \& Essen, M. V. (2016). Home country institutions and the internationalization-performance relationship: A meta-analytic review. Journal of Management, 42(5), 1075-1110.

McCarthy, K. J., \& Aalbers, H. L. (2016). Technological acquisitions: The impact of geography on postacquisition innovative performance. Research Policy, 45(9), 1818-1832.

Mihalache, O. R., Jansen, J. J. J. P., Van den Bosch, F. A. J., \& Volberda, H. W. (2012). Offshoring and firm innovation: The moderating role of top management team attributes. Strategic Management Journal, 33(13), 1480-1498.

Murray, J. Y., Gao, G. Y., \& Kotabe, M. (2011). Market orientation and performance of export ventures: The process through marketing capabilities and competitive advantages. Journal of the Academy of Marketing Science, 39(2), 252-269.

Nguyen, B., Yu, X., Melewar, T. C., \& Gupta, S. (2016). Critical brand innovation factors (CBIF): Understanding innovation and market performance in the Chinese high-tech service industry. Journal of Business Research, 69(7), 2471-2479.

O'Cass, A., \& Weerawardena, J. (2009). Examining the role of international entrepreneurship, innovation and international market performance in SME internationalisation. European Journal of Marketing, 43(11-12), 1325-1348.

Ogasavara, M. H., Boehe, D. M., \& Cruz, L. B. (2016). Experience, resources and export market performance: The pivotal role of international business network ties. International Marketing Review, 33(6), 867-893.

Palmie, M., Zeschky, M., Winterhalter, S., Sauter, P. W., Haefner, N., \& Gassmann, O. (2016). Coordination mechanisms for international innovation in SMEs: Effects on time-to-market and R\&D task complexity as a moderator. Small Business Economics, 46(2), 273-294.

Perri, A., \& Peruffo, E. (2016). Knowledge spillovers from FDI: A critical review from the international business perspective. International Journal of Management Reviews, 18(1), 3-27.

Peterson, R. A., \& Brown, S. P. (2005). On the use of beta coefficients in meta-analysis. Journal of Applied Psychology, 90(1), 175-181.

Piening, E. P., Salge, T. O., \& Schafer, S. (2016). Innovating across boundaries: A portfolio perspective on innovation partnerships of multinational corporations. Journal of World Business, 51(3), 474-485.

Piperopoulos, P., Wu, J., \& Wang, C. Q. (2018). Outward FDI, location choices and innovation performance of emerging market enterprises. Research Policy, 47(1), 232-240.

Rabbiosi, L., \& Santangelo, G. D. (2013). Parent company benefits from reverse knowledge transfer: The role of the liability of newness in MNEs. Journal of World Business, 48(1), 160-170.

Rao, V. R., Yu, Y., \& Umashankar, N. (2016). Anticipated vs. actual synergy in merger partner selection and post-merger innovation. Marketing Science, 35(6), 934-952.

Reeb, D., Sakakibara, M., \& Mahmood, I. P. (2012). From the editors: Endogeneity in international business research. Journal of International Business Studies, 43(3), 211-218.

Ren, S. C., Eisingerich, A. B., \& Tsai, H. T. (2015). How do marketing, research and development capabilities, and degree of internationalization synergistically affect the innovation performance of small and medium-sized enterprises (SMEs)? A panel data study of Chinese SMEs. International Business Review, 24(4), 642-651.

Richter, N. F., Sinkovics, R. R., Ringle, C. M., \& Schlägel, C. (2016). A critical look at the use of SEM in international business research. International Marketing Review, 33(3), 376-404.

Riviere, M., \& Bass, A. E. (2019). How dimensions of internationalization shape the MNE's renewal capability: Multidimensional and multilevel considerations. Long Range Planning, 52(4), 101862.

Rosenbusch, N., Brinckmann, J., \& Bausch, A. (2011). Is innovation always beneficial? A meta-analysis of the relationship between innovation and performance in SMEs. Journal of Business Venturing, 26(4), 441-457. 
Rosenbusch, N., Gusenbauer, M., Hatak, I., Fink, M., \& Meyer, K. E. (2019). Innovation offshoring, institutional context and innovation performance: A meta-analysis. Journal of Management Studies, 56(1), 203-233.

Rousseau, M. B., Mathias, B. D., Madden, L. T., \& Crook, T. R. (2016). Innovation, firm performance and appropriation: A meta-analysis. International Journal of Innovation Management, 20(03), 1650033.

Salomon, R. M. (2006). Spillovers to foreign market participants: Assessing the impact of export strategies on innovative productivity. Strategic Organization, 4(2), 135-164.

Salomon, R., \& Jin, B. (2010). Do leading or lagging firms learn more from exporting? Strategic Management Journal, 31(10), 1088-1113.

Sambharya, R. B., \& Lee, J. (2014). Renewing dynamic capabilities globally: An empirical study of the World's largest MNCs. Management International Review, 54(2), 137-169.

Sasidharan, S., \& Kathuria, V. (2011). Foreign direct investment and R\&D: Substitutes or complements: A case of Indian manufacturing after 1991 reforms. World Development, 39(7), 1226-1239.

Scalera, V. G., Perri, A., \& Hannigan, T. J. (2018). Knowledge connectedness within and across home country borders: Spatial heterogeneity and the technological scope of firm innovations. Journal of International Business Studies, 49(8), 990-1009.

Schwens, C., Zapkau, F. B., Bierwerth, M., Isidor, R., Knight, G., \& Kabst, R. (2018). International entrepreneurship: A meta-analysis on the internationalization and performance relationship. Entrepreneurship Theory and Practice, 42(5), 734-768.

Scott-Kennel, J., \& Giroud, A. (2015). MNEs and FSAs: Network knowledge, strategic orientation and performance. Journal of World Business, 50(1), 94-107.

Sheng, M. L., Hartmann, N. N., Chen, Q. M., \& Chen, I. (2015). The synergetic effect of multinational corporation management's social cognitive capability on tacit-knowledge management: Product innovation ability insights from Asia. Journal of International Marketing, 23(2), 94-110.

Sidhu, J. S., Commandeur, H. R., \& Volberda, H. W. (2007). The multifaceted nature of exploration and exploitation: Value of supply, demand, and spatial search for innovation. Organization Science, $18(1), 20-38$.

Sivakumar, K., Roy, S., Zhu, J., \& Hanvanich, S. (2011). Global innovation generation and financial performance in business-to-business relationships: The case of cross-border alliances in the pharmaceutical industry. Journal of the Academy of Marketing Science, 39(5), 757-776.

Slangen, A. H. L., \& Beugelsdijk, S. (2010). The impact of institutional hazards on foreign multinational activity: A contingency perspective. Journal of International Business Studies, 41(6), 980-995.

Song, J., Asakawa, K., \& Chu, Y. (2011). What determines knowledge sourcing from host locations of overseas R\&D operations?: A study of global R\&D activities of Japanese multinationals. Research Policy, 40(3), 380-390.

Stanley, T. D., \& Doucouliagos, H. (2012). Meta-regression analysis in economics and business. Routledge.

Starbuck, W. H. (2016). 60th anniversary essay: How journals could improve research practices in social science. Administrative Science Quarterly, 61(2), 165-183.

Steel, P., Beugelsdijk, S., \& Aguinis, H. (2021). The anatomy of an award-winning meta-analysis: Recommendations for authors, reviewers, and readers of meta-analytic reviews. Journal of International Business Studies, 52(1), 23-44.

Steinberg, P. J., Procher, V. D., \& Urbig, D. (2017). Too much or too little of R\&D offshoring: The impact of captive offshoring and contract offshoring on innovation performance. Research Policy, 46(10), 1810-1823.

Subramaniam, M. (2006). Integrating cross-border knowledge for transnational new product development. Journal of Product Innovation Management, 23(6), 541-555.

Sun, S. L., \& Lee, R. P. (2013). Enhancing innovation through international joint venture portfolios: From the emerging firm perspective. Journal of International Marketing, 21(3), 1-21.

Tang, R. W., \& Gudergan, S. P. (2018). A meta-analysis of the international experience-ownership strategy relationship: A dynamic capabilities view. Management International Review, 58(4), 541-570.

Taques, F. H., López, M. G., Basso, L. F., \& Areal, N. (2020). Indicators used to measure service innovation and manufacturing innovation. Journal of Innovation and Knowledge, 6(1), 11-26.

Tidd, J. (2001). Innovation management in context: Environment, organization and performance. International Journal of Management Reviews, 3(3), 169-183. 
Tsao, S.-M., \& Chen, G.-Z. (2012). The impact of internationalization on performance and innovation: The moderating effects of ownership concentration. Asia Pacific Journal of Management, 29(3), $617-642$.

Tsao, S. M., \& Lien, W. H. (2013). Family management and internationalization: The impact on firm performance and innovation. Management International Review, 53(2), 189-213.

Tse, C. H., Yu, L. H., \& Zhu, J. J. (2017). A multimediation model of learning by exporting: Analysis of export-induced productivity gains. Journal of Management, 43(7), 2118-2146.

Tsinopoulos, C., Lages, L. F., \& Sousa, C. M. P. (2014). Export experience counts: Exploring its effect on product design change. $R \& D$ Management, 44(5), 450-465.

Ugur, M., Churchill, S. A., \& Luong, H. M. (2020). What do we know about R\&D spillovers and productivity? Meta-analysis evidence on heterogeneity and statistical power. Research Policy, 49(1), 103866.

Un, C. A. (2016). The liability of localness in innovation. Journal of International Business Studies, 47(1), 44-67.

Verbeke, A., \& Forootan, M. Z. (2012). How good are multinationality-performance (M-P) empirical studies? Global Strategy Journal, 2(4), 332-344.

Wadho, W., \& Chaudhry, A. (2018). Innovation and firm performance in developing countries: The case of Pakistani textile and apparel manufacturers. Research Policy, 47(7), 1283-1294.

Wang, C.-F., Chen, L.-Y., \& Chang, S.-C. (2011). International diversification and the market value of new product introduction. Journal of International Management, 17(4), 333-347.

Wang, C. Q., \& Kafouros, M. I. (2009). What factors determine innovation performance in emerging economies? Evidence from China. International Business Review, 18(6), 606-616.

Wang, K., \& Tao, W. (2019). Exploring the complementarity between product exports and foreign technology imports for innovation in emerging economic firms. European Journal of Marketing, 53(2), $224-256$.

Wang, W., \& Ma, H. (2018). Export strategy, export intensity and learning: Integrating the resource perspective and institutional perspective. Journal of World Business, 53(4), 581-592.

Williams, C., \& Du, J. N. (2014). The impact of trust and local learning on the innovative performance of MNE subsidiaries in China. Asia Pacific Journal of Management, 31(4), 973-996.

Witt, M. A. (2019). De-globalization: Theories, predictions, and opportunities for international business research. Journal of International Business Studies, 50(7), 1053-1077.

Woerter, M., \& Roper, S. (2010). Openness and innovation-Home and export demand effects on manufacturing innovation: Panel data evidence for Ireland and Switzerland. Research Policy, 39(1), $155-164$.

Wolff, J. A., \& Pett, T. L. (2006). Small-firm performance: Modeling the role of product and process improvements. Journal of Small Business Management, 44(2), 268-284.

Wu, H., Chen, J., \& Jiao, H. (2016). Dynamic capabilities as a mediator linking international diversification and innovation performance of firms in an emerging economy. Journal of Business Research, 69(8), 2678-2686.

Wu, J. (2013). Diverse institutional environments and product innovation of emerging market firms. Management International Review, 53(1), 39-59.

Wu, J., Wang, C., Hong, J., Piperopoulos, P., \& Zhuo, S. (2016). Internationalization and innovation performance of emerging market enterprises: The role of host-country institutional development. Journal of World Business, 51(2), 251-263.

Wu, J., \& Wu, Z. (2014). Local and international knowledge search and product innovation: The moderating role of technology boundary spanning. International Business Review, 23(3), 542-551.

Wu, J., Wu, Z., \& Zhuo, S. (2015). The effects of institutional quality and diversity of foreign markets on exporting firms' innovation. International Business Review, 24(6), 1095-1106.

Xia, T., \& Liu, X. (2017). Foreign competition, domestic competition and innovation in Chinese private high-tech new ventures. Journal of International Business Studies, 48(6), 716-739.

Xie, Z. Z., \& Li, J. T. (2013). Internationalization and indigenous technological efforts of emerging economy firms: The effect of multiple knowledge sources. Journal of International Management, 19(3), 247-259.

Xie, Z. Z., \& Li, J. T. (2018). Exporting and innovating among emerging market firms: The moderating role of institutional development. Journal of International Business Studies, 49(2), 222-245.

Yang, C. H., \& Hayakawa, K. (2015). Localization and overseas R\&D activity: The case of Taiwanese multinational enterprises in China. R\&D Management, 45(2), 181-195. 
Yang, Y., \& Driffield, N. (2012). Multinationality-performance relationship: A meta-analysis. Management International Review, 52(1), 23-47.

Yi, J. T., Hong, J. J., Hsu, W. C., \& Wang, C. Q. (2017). The role of state ownership and institutions in the innovation performance of emerging market enterprises: Evidence from China. Technovation, 62-63, 4-13.

Yi, J., Wang, C., \& Kafouros, M. (2013). The effects of innovative capabilities on exporting: Do institutional forces matter? International Business Review, 22(2), 392-406.

Zahra, S. A., Ireland, R. D., \& Hitt, M. A. (2000). International expansion by new venture firms: International diversity, mode of market entry, technological learning and performance. Academy of Management Journal, 43(5), 925-950.

Zahra, S. A., Ucbasaran, D., \& Newey, L. R. (2009). Social knowledge and SMEs' innovative gains from internationalization. European Management Review, 6(2), 81-93.

Zhao, H. X., Ma, J. Q., \& Yang, J. (2017). 30 years of research on entry mode and performance relationship: A meta-analytical review. Management International Review, 57(5), 653-682.

Zhou, L. X., \& Wu, A. Q. (2014). Earliness of internationalization and performance outcomes: Exploring the moderating effects of venture age and international commitment. Journal of World Business, 49(1), 132-142.

Zhou, L. X., Wu, A. Q., \& Barnes, B. R. (2012). The effects of early internationalization on performance outcomes in young international ventures: The mediating role of marketing capabilities. Journal of International Marketing, 20(4), 25-45.

Publisher's Note Springer Nature remains neutral with regard to jurisdictional claims in published maps and institutional affiliations. 